\title{
Oyun Adlarının Türkiye Türkçesi Ağızlarında Kullanımı Üzerine Bir Değerlendirme ${ }^{1}$
}

\author{
Türker Barıș BULDUK \\ Dr. Öğr. Üyesi, Adıyaman Üniversitesi, Fen Edebiyat Fakültesi, \\ Türk Dili ve Edebiyatı Bölümü \\ turkerbulduk@gmail.com \\ Orcid ID: https://orcid.org/0000-0002-0423-837X
}

\begin{abstract}
Öz
Gerek halk oyunlarının gerekse çocuk oyunlarının Türklerin yaşantısında, çok eski dönemlerden bu yana, ne denli önemli olduğu bilinen bir gerçekliktir. Bu oyunların büyük bir kısmı kendiliğinden ortaya çıkmış ve yaşamın bütünleyici bir ögesi olmuştur. Buna bağlı olarak, Türk kültüründeki oyun çeşitliliği hemen her bölgemizde azımsanmayacak bir zenginlik arz etmektedir. Buna rağmen bu oyunların hem oynanma biçimleri hem de adları, yaşam şartlarının ve eğlence anlayışının değişmesiyle zamanla unutulmaktadır. Birçok toplum, değişen teknoloji ile birlikte unutulmaya başlamış olan oyunlarını koruma altına alarak sonraki kuşakların bu kültürel mirastan faydalanmasına olanak sunmaktadır. Anadolu'daki çocuk oyunlarının ve halk oyunlarının oynanma biçimleri üzerine birçok çalışma yapılmışsa da bu oyunların neler olduğu üzerine kapsamlı bir değerlendirme yapılmamıştır. Bu araştırma, Türkiye Türkçesi ağızlarındaki söz varlığına dayalı bir çalışma olup Türk kültüründe önemli bir yeri olan çocuk oyunları ve halk oyunları başta olmak üzere, Türkiye Türkçesi ağızlarındaki bütün oyun adlarının kullanımlarını tespit etmeye yöneliktir. Bu kapsamda, Derleme Sözlüğü'ne ek olarak Türkiye Türkçesi ağızları üzerine hazırlanmış kitap ve lisansüstü tezler taranmış, ağızlarda varlığını sürdüren birçok oyun adının Türkiye Türkçesinde kullanılmadığı görülmüştür. Ayrıca Türkiye Türkçesi ağızlarındaki oyun adlarının büyük bir bölümünün Türkçenin morfolojik özelliklerine uygun olmadığı tespit edilmiş̧ir.
\end{abstract}

Anahtar Kelimeler: Ağız, Türkiye Türkçesi Ağızları, Oyun, Çocuk Oyunları, Halk Oyunları.

\footnotetext{
${ }^{1}$ Makale Geliş/Kabul Tarihi: 31.07.2019 / 24.10.2019

Künye Bilgisi: Bulduk, T. B. (2019). Oyun Adlarının Türkiye Türkçesi Ağızlarında Kullanımı Üzerine Bir Değerlendirme. Kahramanmaraş Sütçü İmam Üniversitesi Sosyal Bilimler Dergisi, 16 (2), 394-443. DOI: 10.33437/ksusbd.621733
} 


\title{
An Assesment About Usage Of Game Names In Turkey Turkish Dialects
}

\begin{abstract}
It is a crucially-known fact that both folk dances and children's games have been significant in Turkish lifestyle ever since ancient times. A good number of these games emerged spontaneously and became an complementary part of life. In parallel with, the variety of games in Turkish culture presents a considerable worth in nearly every region of us. Nevertheless, both the forms and names of play are forgotten over time with changing living conditions and perception of entertainment. Plenty of societies protect the games that have been forgotten with the changing technology and transfer them to the next generations so that they can benefit from this cultural heritage. Even though many studies have been conducted on outline procedures of children's game and folk dances in Anatolia, no comprehensive assesment has been made on what these games are. Basically, this survey is based on to point out presence of the vocabulary in Turkey Turkish dialects and focusing on children's games which have important role in Turkish culture to determine usage of all games in Turkey Turkish dialects. Within this perspective, in addition to Assembly dictionary, books and postgraduate thesis are examined and it is ultimately determined that plenty of games which are still in dialects are not used in Turkey Turkish. It is also determined that a great proportion of game names in Turkey Turkish dialects are not corresponded with morphological patterns of Turkish.
\end{abstract}

Keywords: Dialect, Turkey Turkish Dialects, Game, Child Games, Folk Dances.

\section{GİRIŞ}

İnsan sosyal, kültürel ve biyolojik bir varlıktır. Biyolojik bir varlık olarak insan, canlılığını devam ettirebilmek için yemek, içmek, uyumak gibi birtakım fizyolojik eylemlere ihtiyaç duyar. İnsan için nasıl ki yemek, içmek ve uyumak fizyolojik bir ihtiyaç ise oyun da insan hayatının bütününde ya da belirli bir döneminde etkili olan fizyolojik bir ihtiyaçtır.

Oyunun tarihi insanlık tarihi kadar eskidir. En eski oyuncakları MÖ 5. yüzyılda Misırlıların kullandığı bilinse de her toplumun tarihi çok eskilere dayanan ve haz duygusuyla oyuna giren her bireyin bu oyunu gelecek kuşaklara aktardığı birçok oyunu bulunmaktadır. Türk kültüründe de bu nitelikte birçok oyun bulunmaktadır. Metin And, oyun kelimesinin Türkçenin en eski 
kelimelerinden biri olduğunu ve kökeninin, şaman töreninin tamamına verilen ad olarak Şamanlıktan geldiğini belirtmektedir (And, 2003: 37). Şamanlar bu törenlerde belirli bir ezgi eşliğinde bir çeşit dans eder, birtakım sesler çıkarır ve çeşitli taklitler yaparlardı. Halk oyunlarının dinsel birtakım ritüeller ile bağlantılı büyüsel bir yönünün olduğu, hem Türklerdeki şaman törenlerinden hem de Eski Yunan'daki Dionisos şenliklerinden çıkarılabilir. Çeşitli toplumlarda var olan bu gelenek, bugün halk oyunu olarak karşımıza çıkmaktadır.

Halk oyunu, ait olduğu toplumun kültürel göstergesi ve kimliğini ifade etme biçimidir. $\mathrm{Bu}$ durum, insanın bazen yaşadığ 1 çevre ile, tabiat ile, farklı hayvan türleriyle ya da kendi ürettikleriyle ilgili olabilmektedir. Kavga, savaş, hasat, vahşi hayvanlara karşı korunma, arazi anlaşmazlıkları, barış gibi olaylar halk oyunlarımıza yansıyan birkaç örnek olarak gösterilebilir. Halk oyunlarının en önemli özelliği yerelliktir. Anadolu' da her köşesinde farklı farklı icra edilen halk oyunları, toplumsal yaşamın her döneminde insanın yaşamında farklı bir biçimde yer almış ve toplumsal bütünlügü sağlamış önemli bir öge olmuştur. (Bali, 2017: 78-83).

Çocuk oyunları da, tıpkı halk oyunları gibi, kültürün sonraki kuşaklara aktarılmasında önemli bir konumdadır. Çocuğun sosyalleşmesinde önemli bir rolü olan çocuk oyunlarının tarihi de çok eskilere dayanmaktadır. Kazılarda elde edilen eserler ile hiyeroglifler incelendiğinde Eski Mısır'da topaç, tahta at ve oyuncak bebeklerle ilgili çeşitli oyunlar oynandığ 1 söylenebilmektedir. Yine Eski Yunan, Roma ve Çin uygarlıklarında da misket, topaç gibi çeşitli çocuk oyunlarının oynandığına dair bulgular olduğu bilinmektedir.Çocuk oyunları ve bu oyunlarda kullanılan oyuncaklar çocuğun fiziksel becerilerini geliştirmenin yanı sıra zihinsel gelişimine de katk1 sunmaktadır. Bugün, Anadolu'da unutulmaya yüz tutmuş çocuk oyunlarında kullanılan temel malzemeler taş, sopa, ip ve top gibi herkesin kolayca ulaşabileceği türdendir. Ancak çocuğun gelişiminde çok önemli bir rolü bulunan oyun ve oyuncaklar teknolojik gelişmelere bağlı olarak farklılaşmaktadır. Eskiden oynanan oyun ve oyuncaklar her geçen gün şekil değiştirmekte ve taş, sopa, ip ve top gibi oyuncakların yerini lego, uzaktan kumandalı araba, barbie bebek, robot ya da bilgisayar oyunları almaktadır. Fakat bu oyunlar, çocuğun özellikle zihinsel gelişimini olumsuz etkilemekte ve çocuğun sosyalleşmesini engellemektedir. Birçok toplum, değişen teknoloji ile birlikte unutulmaya başlamış olan çocuk oyunlarını ve oyuncaklarını koruma altına alarak sonraki kuşakların bu kültürel mirastan faydalanmasına olanak sunmaktadır. Zengin bir çocuk oyunu kültürüne sahip olan Anadolu'daki bu oyunların tümüyle ortadan kalkmadan derlenmesi ve bu derlenen oyunların çocukların eğitiminde etkin bir biçimde kullanılması gerekmektedir (Başal, 2007: 245-247). 
Türkçenin en önemli eserlerinden biri olan Dîvânu Lugâti’t-Türk’te deçenğli menğli 'bir çocuk oyunu, salıncak oyunu' (Atalay, 2018: 141) karagun 'akşemleyin çocukların oynadıkları bir oyun' (Atalay, 2018: 266); köçürme oyun 'on dört adı verilen bir oyun' (Atalay, 2018: 354); münğüz münğüz 'bir çeşit çocuk oyunu (Atalay, 2018: 417); ötüş / ütüş 'bir çeşit çocuk oyunu' (Atalay, 2018: 470.719) ve yalnğu 'cariyelerin oynadığı bir oyun, salıncak oyunu' (Atalay, 2018: 736) şeklinde yedi oyun adının geçmesi de Türk kültüründe oyunun yerini belirtmesi bakımından önemli bir göstergedir.

Kültürümüzde çok eski zamanlardan bu yana yaşayan oyunlar, Anadolu'nun farklı ekonomik, sosyal, fizikî şartlarına ve iklim özelliklerine bağlı olarak farklı oynanma biçimlerinde ve farklı adlarla karşımıza çıkabilmektedir. Anadolu'da yöreden yöreye farklılık gösteren anlamıyla kullanılan "yöresel" kavramının oyun adları için de olduğu söylenebilir. Anadolu'da her yörenin nasıl ki düğün müziği, yemeği, bayram algısı farklılaşıyorsa oyunlar da yöreden yöreye farklılık göstermektedir. Bu çalışma ile birçoğu binlerce yıllık bir geçmişe sahip olan ve Anadolu'da farklı biçimlerde ve farklı adlarla oynanan oyun adları, Türkiye Türkçesi ağızları taranarak bir araya getirilecektir. Çocuk oyunları, halk oyunları ve diğer oyunlar olarak sınıflandıracağımız bu çalışmada esasen şu sorulara cevap aranacaktır:

1. Türkiye Türkçesi ağızlarında hangi çocuk oyunları vardır?

2. Türkiye Türkçesi ağızlarında hangi halk oyunları vardır?

3. Türkiye Türkçesi ağızlarında varlığını devam ettiren diğer oyun adları nelerdir?

4. Türkiye Türkçesi ağızlarında yaşayan bu adlardan hangileri Türkçe Sözlük'te bulunmaktadır?

$\mathrm{Bu}$ sorulara cevap ararken araştırma verilerimizi, araştırmanın amacına uygun olarak, Türkiye Türkçesi ağızları ile ilgili yazılan kaynakları tarayarak elde edeceğiz. Bu doğrultuda Türkiye Türkçesi ağızları ile ilgili yapılmış en kapsamlı çalışma olan Derleme Sözlüğü'ne ek olarak ağızlar ile ilgili hazırlanmış kitaplar ve lisansüstü tezlere de başvurulacaktır. Bir oyun adının hangi ağılarda ne şekilde kullanıldığı ve bunun Türkçe Sözlük’te karşı1lı̆ının olup olmadığ 1 bu çalışmada değerlendirilecektir.

Türk kültüründeki oyunlar üzerine bugüne kadar çok değerli çalışmalar yapılmıştır. Halk oyunları ile ilgili en kapsamlı çalışmaları, Sadi Yaver Ataman "100 Türk Halk Oyunları"; Şerif Baykurt "Türk Halk Oyunları"; İlknur Bektaş "Türk Halk Oyunlarında Tasnif Şekilleri; Ahmet Çakır "Türk Halk Oyunlarının Tasnifi”; Cemil Demirsipahi “Türk Halk Oyunları”; İsmail Ekmekçioğlu "Türk 
Halk Oyunları"; Şebnem Erçil “Türk Halk Oyunlarında Oyun Teknikleri”; M. Ragıp Gazimihal "Türk Halk Oyunları Kataloğu” adlı çalışmalarla yapmışlardır.

Çocuk oyunları ile ilgili ise, Yusuf Ziya Demircioğlu "Anadolu'da Eski Çocuk Oyunları; Ferruh Arsunar "Türk Çocuk Oyunlarından Örnekler"; Musa Baran "Çocuk Oyunları"; Nebi Özdemir "Türk Çocuk Oyunları" ve Necati Demir "Anadolu'dan Türk Çocuk Oyunları"adlı çalışmalarla öne çıkmaktadırlar. Elbette bütün bu çalışmalar Türk kültüründeki halk oyunlarının ve çocuk oyunlarının oynanma biçimleri üzerinedir. $\mathrm{Bu}$ çalışmada ise, Anadolu kültüründeki oyunların oynanma biçimlerinden ziyade Türkiye Türkçesi ağızlarındaki kullanımları üzerinde durulacaktır.

Bugüne kadar çeşitli araştırmacılar tarafından Türkiye Türkçesi ağızları söz varlığındaki birçok kavram üzerine çalışmalar yapılmıştır. Zeki Kaymaz Türkiye Türkçesi ağızlarında renk bildiren kelimelerin kullanımı üzerine; Şerif Ali Bozkaplan ağızlardaki güzel adlandırmalar üzerine çalışmışlardır. Yine, Serdar Yavuz Türkiye Türkçesi ağızlarındaki akrabalık adları ile ilgili; Berker Kurt ağızlardaki organ adları ile ilgili ve Oğuz Ergene ağızlardaki hayvan adları ile ilgili çalışmışlar yapmışlardır. Türkiye Türkçesi ağızlarındaki söz varlığı üzerine hazırlanmış lisansüstü tezler de bulunmaktadır. M. Fatih Alkayış ağızlardaki bitki adları üzerine doktora tezi; Meliha Kekilli ağızlardaki yemek adları üzerine ve Cemal Okçu ise ağızlardaki tarım sözcükleri üzerine yüksek lisans tezleri hazırlamışlardır. Biz ise bu çalışmada, ağızlardaki oyun adlarının kullanımları üzerinde duracağız.

\section{Türkiye Türkçesi Ağızlarında Çocuk Oyunları}

ahletgakı: Yassı taşlarla oynanan bir çocuk oyunu (DS, 4412).

ağat: Bilye oyunu (DS, 2009: 85).

alda: Bir çocuk oyunu (DS, 209).

aluk: Aşık kemiği ve bu kemikle oynanan oyun (DS, 234).

amata: Taşla oynanan bir çocuk oyunu (DS, 237).

analık: Bir çeşit çocuk oyunu (DS, 251).

anası āri: Uzun değneklerle oynanan çocuk oyunu (SİYA, 556).

angili bingili: Tahterevalli oyunu (GA, 21).

aplamsıra: Birdirbir oyunu (DS, 289). 
aragetdi: Bir tür çocuk oyunu (GA, 22; GŞKA, 281).

ara kesme: Saklambaça benzeyen bir çocuk oyunu (ÇA, 562).

ara kesti: Daire içinde ve dışında yirmişer kişilik gruplarla oynanan bir çocuk oyunu (DS, 295; SIYA, 557).

ara kitli: Bir çocuk oyunu (AA, 691).

arıdız: Bir tür çocuk oyunu (GA, 24; GŞKA, 281).

artırmaç [artırma, arttırmaç]: Bir çeşit çocuk oyunu (DS, 335; SiYA, 558).

aşbincik [aşbiş, aşpincik]: Çocukların yemek oyunu (DS, 351).

aşık [aşıg்]: Hayvanların mafsallarından çıkan kemikle oynanan bir çocuk oyunu (AİYA, 17; TIYYA, 447; AMA, 296).

aş1lamaç: Bir çocuk oyunu (DS, 354).

ateşleme [ateşli, ateşlim]: Bir çeşit çocuk oyunu (DS, 368; RİA, 310).

atıl hömbek: Bir çeşit uzun eşek oyunu, atlambaç (DS, 368).

atlandı: Bir çeşit çocuk oyunu (DS, 371).

atmalı: Çocukların oynadığı bir ceviz oyunu (DS, 372).

atma taş: Çocukların oynadığı bir taş oyunu (DS, 372).

ayağım nallı: Bir çocuk oyunu (AA, 706).

ayağım yağlı: Tek ayak üstünde oynanan bir çocuk oyunu (DS, 398).

ayahdaş1: Seksek, kaydırak oyunu (DS, 399).

ayah sayma: Daire şeklinde oturan çocukların tekerleme eşliğinde oynadıkları Adıyaman yöresine özgü bir oyun (AİYA, 19).

ayaktaşı: Çocukların yere çizdikleri şekiller üzerinde taşla oynadıkları bir çeşit oyun (DS, 404).

ayamaya: Çokça kızların oynadığı bir oyun (DS, 406).

baba yıkmaca: Bir çizgi çizilerek oynanan ve çizginin bulunduğu yerden ebenin bulunduğu noktaya taşı en yakın atmak suretiyle ebe belirlenip oynanan oyun (KRA, 68). 
baç: Çocuklar arasında esir almaca oyunu (DS, 458).

baçç1: Ucu sivri değnek yere saplanarak oynanan çocuk oyunu (DS, 4440).

badis: Boncuklarla oynanan bir çocuk oyunu (DS, 4441).

badrambaz: Yağmursuz mevsimlerde yağmur yağdırmak için çocukların birbirini 1slatarak oynadıkları bir oyun (DS, 471).

ballı callı: Bir çeşit aşık oyunu (DS, 509).

bandık geldik: Bir çocuk oyunu (DS, 517).

basmaç: Yazı tura oyunu (DS, 544).

bastı: Ortaya dikilen bir çubuğun vurulmaya çalışıldığı bir oyun (ÇA, 569).

baştan donma: Dörder kişilik kümelerin birbirleri üzerinden takla atmalarıyla oynanan çocuk oyunu (RİA, 311).

batçı: Bir çocuk oyunu (DS, 570).

battı balık: 8-10 kişi ile oynanan bir çocuk oyunu (DS, 573).

batt1 batt1 [battal, batt1, batti batti, batdi batdi, batti bitti]: Değnekle oynanan bir çocuk oyunu (DS, 573; BA, 850; ÇA, 569; VHA, 789).

bazlambaç [bazlamaç, bazlanbaç]: Birdirbir de denilen bir çocuk oyunu (DS, 589; SIYA, 568).

benziboz: Bir çeşit çocuk oyunu (DS, 630).

beşbeş: Çocukların kâğıt üzerinde kalemle oynadıkları bir oyun (DS, 642).

beş kaya: Beş taşla oynanan bir çocuk oyunu (DS, 644; KRA, 77; HAA, 386).

bıcı bıcı: Bir çeşit çocuk oyunu (DS, 654).

bıçgın: İki değneği birbirine sürterek havaya firlatma oyunu (DS, 655).

billik tutma: Tutulan bir şeyin hangi elde olduğunu bulma oyunu (DS, 667).

bır: Sopayla oynanan bir çocuk oyunu (DS, 668; VHA, 791; VMA, 437).

biççili: Beştaş oyunu (DS, 683).

bila: Bilye oyunu (DS, 689). 
binme oyunu: Adıyaman yöresinde oynanan bir çocuk oyunu (AİYA, 31).

birik: Çocukların koşarak oynadıkları bir oyun (DS, 701).

birliğim birlik: En az üç kişi ile oynanan ve gönüllü bir ebenin okuduğu tekerlemeyi tekrar eden diğer oyuncularla oynanan Adıyaman yöresine özgü bir oyun (AİYA, 32).

bitti [bitti bibik, bitti bitti, bittik]: 1. Saklambaç oyunu. 2. Çocukların, ucu sivriltilmiş ağacı yere vurup saplayarak oynadıkları oyun (DS, 712).

bokuç: Yuvarlak taşlarla oynanan oyun (GGA, 250).

bolu yağması: Çocukların, çukurlara taş koyarak oynadıkları bir oyun (DS, 735).

boncuk oyunu: Para, düğme, boncuk gibi şeylerle oynanan bir çocuk oyunu (DS, 736).

bosdanacan: Birdirbir oyununa benzer bir oyun (DS, 742).

bozlak: Bir çeşit çocuk oyunu (HAA, 387).

bozlambaç: Birdirbir oyunu (DS, 752).

bucuk [bıcık]: 4-5 kişi ile oynanan bir çocuk oyunu, hot (DS, 777).

buru: Kozalak ve sırıkla oynanan bir oyun (DS, 802).

cancan: Ağaç çubuklarla oynanan bir çocuk oyunu (DS, 855).

caynız: Bir çeşit çocuk oyunu (AA, 785).

cıka: Taşla oynanan çocuk oyunu (DS, 905).

cıkcırım: Yere çizilen çizgi üzerinde taş sürerek oynanan oyun (GA, 71).

cınapır: Körebe oyunu (DS, 918).

cingılız: Bir çocuk oyunu (DS, 922).

cınğıllı: Bir çeşit saklambaç oyunu (DS, 924; GA, 73).

cıpcıp: İki çocuğun karşılıklı, ellerini birbirine vurup yüzlerine dokunarak oynadıkları oyun (DS, 924).

cısk: Adıyaman yöresinde oynanan bir tür çocuk oyunu (AİYA, 44). 
cıtdi pıtdi [cıtdıbıdı]: Saklambaç oyunu (GA, 75; GŞKA, 282).

cıttır cıbıh̆: İki kişinin sırt sırta dönüp kollarını birbirine geçirerek birbirlerini kaldırma oyunu (DS, 941).

cızbız: Altı taş oyunu (DS, 946).

cızgıt [cızğırik oyunu, cızıkam]: Düz ve kaygan bir taşı, yere çizilmiş çizgiler üzerinden, tek ayakta iterek geçirme, çizgi oyunu (DS, 947; GA, 76).

c1zı oyunu [cız]: Bir çeşit aşı oyunu (DS, 950; KAKD, 390).

cızıl1 [cızgıl1]: Çocukların seksek oyunu (DS, 950; KYA, 466).

cibide: Bilye oyunu (DS, 955).

cicibici: Renkli fasulyelerle oynanan çocuk oyunu (DS, 958).

ciccavvar: Kuyu etrafında dönerek oynanan çocuk oyunu (DS, 958).

cicoz: Yüzük oyunu (DS, 960).

cimcicik: Beştaş oyunu (DS, 4475).

cimcim [cimcik oyunu]: Çocukların ellerini üst üste koyarak oynadıkları bir çeşit oyun (DS, 971; GA, 79; SIYYA, 580).

cincan: Topla oynanan bir çeşit çocuk oyunu (DS, 975).

cinci: Çocuklar arasında oynanan ve korkutmaya dayanan bir oyun (MA, 1215).

cincik makarna: Bir çocuk oyunu (DS, 976).

cincon: Topla oynanan bir çocuk oyunu (DS, 976).

coli: Körebe tarzında bir çocuk oyunu (VHA, 799).

cor: Çocuk oyunu (DS, 1000).

corcor: İki gruba ayrılan çocukların bir kısmının yere çizilen daire içine, bir kısmının dışına sıralanarak oynadıkları oyun (DS, 1001).

cu: Bir çeşit çocuk oyunu (DS, 1008).

cukcuk: Topu havaya atarak oynanan bir çeşit oyun (DS, 1011).

cundum: İki kişinin taşla oynadıkları bir çeşit oyun (DS, 1017). 
curruk: Bir çeşit çocuk oyunu (DS, 1019).

cük: F1stık kabuğu ve erik çekirdeği ile oynanan oyun (DS, 1025).

cüllülük: Bir çeşit çocuk oyunu (DS, 1026).

cüz: Dokuz taş oyunu (DS, 1029; GA, 82).

çabçabuh: Çelik çomak oyunu (DS, 1030).

çakma top: Bir çocuk oyunu (BA, 858).

çalçubuh: Çelik çomak oyunu (DS, 1050).

çamçakır: Gece oynanan bir çocuk oyunu (DS, 1064).

çant1: Sırıklar birbirine vurularak oynanan oyun (DS, 1071; OAAD, 228).

çarçarı: Birdirbir oyunu (DS, 1080).

çatal matal: Bir çeşit çocuk oyunu (DS, 1088).

çaylak kapışmak: Bir çeşit oyun (DS, 1097).

çekdiri: Yirmi dört taşla oynanan bir oyun (DS, 1108).

çelik [çelik çomah, cellik, çelikmen, çellik, çelme çelik, çelik gabal, çelüh]: Çocukların sopa ile oynadıkları oyun (DS, 1123; AA, 799; GA, 93; GŞKA, 282;

KRA, 97; HAA, 387; TYA sz. 57; SIYA, 585).

çellek: Çelik çomak oyunu (DS, 1124).

çetük: Kaydırak oyunu (DS, 1152).

çevirgeç: Çocukların oynadıkları bir çeşit oyun (DS, 1152).

çevrim çiçek [çevren çiçek]: Çocukların kendi etraflarında dönerek oynadıkları bir oyun (DS, 1154; AA, 801).

çıhtımçıh: Adıyaman'a özgü bir oyun (AİYA, 52).

ç1llk: Koşmaca oyunu (DS, 1174).

çır: Erkek çocuklar tarafından oynanan kale oyunu (DS, 1184; TYAD, 170).

çırakman: Erkek çocuklar tarafından ufak bir çukura bir makara kukasını koymak için sopalarla vurularak oynanan bir çeşit oyun (DS, 1185; KRA, 101). 
çırtik: Altı kare biçiminde çizilerek oynanan çocuk oyunu (TYAD, 170).

çıtak: Taş oyunu (DS, 1192).

çiftelik: Bilye oyunu (DS, 1205).

çik: Bir çocuk oyunu (KYA, 468).

çilem: Bir çeşit çocuk oyunu (HAA, 387).

çillik [çilih]: Körebe oyunu (DS, 1219; KİA, 374).

çinçin: Tek ayak üzerinde sekerek oynanan bir çocuk oyunu (DS, 1226).

çitbit: Bir çeşit çelik çomak oyunu (DS, 1241).

çitime oyunu: Büyükçe bir daire çizilerek ortasına ceviz, aşık veya çekirdek dikilir. Oyuna katılanlar dikdörtgen şeklindeki küçük taşla, bu daire içindeki cevizi çıkarmaya çalışır, çıkarılan cevizler çıkaran kimsenin olur (DS, 1245).

çitme: Eski bakır paraları duvara çarpmak ve birbirine yakın düşürmek suretiyle çocukların oynadığı bir kumar (DS, 1247).

çizi: Bir çeşit aşık oyunu (DS, 1253).

çoban kızı: Çocuklar arasında oynanan bir oyun adı (KRA, 105).

çom oyunu: Değneklerle oynanan bir çeşit çocuk oyunu (DS, 1266).

çortlik: Çocukların sopalarla oynadıkları bir çeşit oyun (DS, 1273).

çota [çotu]: Değneklerle oynanan bir çeşit çocuk oyunu (DS, 4482; ÇA, 586).

çoturum eşeği: Uzun eşek oyununun diğer bir ismi (DS, 1275).

çömçe gelin: Çocukların süpürgeyi gelin yaparak oynadıkları oyun (DS, 1285; VHA, 806).

çömçöm [çöm çöm direk]: Bir çocuk oyunu (DS, 1285; AA, 814).

çönçel: Yöresel bir oyun adı (KSA, 443).

çöplen: Bir çeşit çocuk oyunu (DS, 1290).

çörçör: Bir çeşit çocuk oyunu (DS, 1291).

çöte: Sopayla oynanan bir oyun (HAA, 388). 
çöttük: Bir çeşit çocuk oyunu (DS, 1297; SİYA, 590).

çüncülü: Ucu kırık sopalarla iki bölük arasında oynanan bir çeşit top oyunu (DS, 4483).

çüş bindim çürüğe: Bir çocuk oyunu (SiYA, 590).

dalloğ: Üç taş oyunu (DS, 1346).

damaklı met: Çelik çomak (DS, 1349).

dana [dandirik]: Uzun değneklerle yuvarlak bir taşa vurarak oynanan çocuk oyunu (DS, 1355).

danaküçü: Çocukların uzun bir değnekle bir kemik parçasına vurarak oynadıkları oyun (DS, 1356).

dandiliçüş: Tahterevalli oyunu (DS, 1358).

dangalafışti: Tahterevalli oyunu (GA, 114).

dangılıkırma: Tahterevalli oyunu (DS, 1359).

daryand1 [darıyand1]: Tura ile oynanan oyun (DS, 1374; OAAD, 230).

daş oyunu: Taşlarla oynanan bir çocuk oyunu (TYA, sz. 68).

dēerme çalma: Topaç oynama (DS, 1399).

degişme: Aldatarak oynanan kar topu oyunu (DS, 1400).

delikçe [delik]: Yere çukurlar kazarak oynanan bir çeşit oyun (DS, 1412; KRA, 111).

dengire: Çoğunlukla okul çağına gelmemiş çocukların oynadığı bir oyundur. Bir sıraya dizilen çocuklar değneklerinin yaylandırdıktan sonra birden firlatırlar. Değneği en geride kalan çocuk ebe olur ve değneğini bir sıraya dizilmiş olan çocuklara paralel olarak yere koyar. Birer birer değneklerini firlatan çocuklar ebenin değneğine vurarak uzaklaştırmaya çalışırlar. Hiç biri değneğe vuramazsa ebeyi şaşırtarak değneklerini almaya çalışırlar. Bu arada ebe onlardan birini yakalarsa ebe değişir, yakalayamazsa yine kendisi ebe olur ve oyun devam eder (DS, 1424).

dıngılapışdo: Tahterevalli oyunu (DS, 1464).

dız: Bir çeşit çocuk oyunu (GA, 125; GŞKA, 282). 
dibiş degenek: Çelik çomak oyunu (DS, 1480).

dikme çelik: Yere dikilmiş bir direk üzerine çelik konarak oynanan çelik çomak oyunu (DS, 1489).

diktağan: Taşlarla oynanan bir çeşit çocuk oyunu (DS, 1490).

dilbedirik: Sopalarla oynanan bir çeşit çocuk oyunu (DS, 1491).

dilġoz: Çocukların oynadığı bir oyun adı (MA, 1220).

dim: Bir çeşit bilye oyunu (GGA, 257).

dittimiç: Topu kazılan çukura sopayla atarak oynanan bir çocuk oyunu (DS, 1526).

dokurcun [dokurcum]: Dokuztaş oyunu (DS, 1541).

doķuz kiremit: Topla oynanan bir çocuk oyunu (KDA, 434).

dolamaç: Saklambaç oyunu (DS, 1543).

domaç: Aşı1k kemiği ile oynanan bir oyun (DS, 1548).

domuzcuk [domuz]: Çocukların oynadığı bir oyundur. Kazılan çukur üzerine çubuklar dizilir. Bu çubukların üstünde gezerken kim çukura düşerse o domuzcuk olur. Hep birden domuzcuk diye bağırılır (DS, 1555).

don: Kovalamaca şeklinde oynanan bir oyun (KRA, 120).

donuz oyunu: Ağaçtan yapılan, küçük top büyüklügündeki donuz ile oynanan bir çocuk oyunu. Ebe, açılan çukura donuzu sokmaya, diğer çocuklar da sopa ile buna engel olmaya çalışırlar (DS, 1562).

dostak: Değnek ve topaç ile oynanan bir çocuk oyunu (DS, 1567).

döndermec: Aşıkla oynanan bir oyun (DS, 1581).

durtut: Bir çeşit çocuk oyunu (DS, 1606).

düllük [düllek]: Çelik çomak oyunu (DS, 1628, 4490).

düngülüş: Çelik çomak oyunu (DS, 1631).

düşmeli aşık: Kaybedenin aşığını vermesi suretiyle oynanan bir oyun (DS, 1639). 
düz: Kare şeklinde çizilmiş ve dörde bölünmüş bir yüzey üzerinde üçer taşla iki kişi tarafindan oynanan bir çeşit oyun (DS, 1643).

ebekaç: Saklambaç oyunu (SIYA, 602).

el epenek: Bir çeşit çocuk oyunu (SIYYA, 604).

elbende: Çocukların birbirine el vurup kaçarak oynadıkları bir oyun (GA, 145).

elbürgeç: Birdirbir oyunu (DS, 1704).

eldaş1 [eldaş1 oyunu]: Bir çeşit taş oyunu ki bunu en çok kızlar oynar (DS, 1707).

el eli ebem eli: El el üstünde kimin eli var oyunu (DS, 1710).

elellezi: İki takım hâlinde oynanan bir oyun (Takımlardan birinden bir oyuncu, diğer takımdaki oyunculara vurabilmek için takımın içine girer, vurabildiklerine yakalanmadan kendi tarafına kaçarsa vurdukları, kaçamazsa kendisi oyun dışı edilir.) (DS, 1710).

elhami gödelek: Taş ve teneke kutu ile oynanan bir çocuk oyunu (SIYYA, 604).

elik çelik: Çelik çomak oyunu (DS, 1717).

elim ateş: Genellikle dört ila on kişi arasında oynanan bir oyun (KRA, 128).

elim elim öpelek: Küçük çocukların oynadıkları bir çeşit oyun (DS, 1718).

elim tuvar: Adıyaman yöresinde oynanan bir çocuk oyunu (AİYA, 80).

elimucu: Bir başkasına elini vurup ebeliği ona devrederek oynanan bir oyun (DS, 1718).

elim yağlı: Çoçukların oynadıkları koşmaca oyunu (DS, 1718).

elketek: Beş taş oyunu (DS, 1719).

ellep: Beş ya da on taşla oynanan oyun (DS, 1721; ÇA, 600).

elpapa: El üstünde oynanılan taş oyunu (DS, 1727).

eltaşı: Beştaş oyunu (DS, 1728; SiYA, 605).

emen: Saklambaç oyunu (DS, 1733).

eme: Bir çeşit taş oyunu (DS, 1733). 
emen oyunu: Üç arkadaşla oynanan bir çocuk oyunu (DS, 1734).

etmeze: Birdirbir oyunu (DS, 1799).

evcik: Evcilik adı da verilen bir çocuk oyunu (AA, 903).

fanti: Çocukların kibrit kutularının dış yüzüyle oynadıkları bir tür kağıt oyunu (VHA, 819; VMA, 458).

fileke: Yass1, hafif taş ve bu taşlarla oynanan oyun (DS, 1864).

fincan: Fincanlara herhangi bir nesnenin saklanmasıyla oynanan oyun (GA, 164; GŞKA, 283; VHA, 820).

fodik [fotik]: Elde taşlarla oynanan bir çeşit çocuk oyunu (DS, 4507; TIYYA, 451).

gadı: Çocukların değnekle oynadıkları bir oyun (DS, 1890).

gala: Dikili taşla oynanan bir çeşit çocuk oyunu (SIYYA, 613).

ġarış oyunu: Bir çocuk oyunu (BA, 889).

gazgıç: Çocukların yere küçük kazık saplayarak oynadıkları bir oyun (DS, 1954).

gıcırgıç: Yüz yirmi cm'lik ucu yontulmuş direk toprağa gömülüp dört metrelik kalın ağacın ortası oyularak çakılın kazığın üzerine konulan ağacın üzerine binilerek oynanan Adıyaman'a özgü bir oyun (AİYA, 101).

ġıldırğış [gıldırgıç]: Çelik oyununa verilen ad (AA, 959; GA, 198).

ġıtik: Bir tür çocuk oyunu (BA, 893).

ġırcı̇ [kırcik]: Taşla oynanan Adıyaman'a özgü bir çocuk oyunu (AİYA, 102).

ġış taḩlası: Bir çeşit çocuk oyunu (GA, 201; GŞKA, 284).

gildirgiç: Yassı taşlarla oynanan bir çeşit oyunu (SİYA, 621).

gili [gigi]: Yere çukurlar açılarak, hayvan tüyünden yapılmış topla oynanan oyun (DS, 2077; SIYA, 621).

gizlembeç [gizdempoç, gizlenpaç, gizlengiz, kizlembeş]: Saklambaç oyunu (OAA, 136; TYAD, 173; KİA, 377; TYA, sz. 156; SIYA, 621).

goldaş1: Taşın elle atılmasıyla oynanan oyun, gülle (GA, 205; GŞKA, 284).

goşto: Adıyaman yöresine ait bir çocuk oyunu (AİYA, 108). 
gödelek: Saklambaç oyunu (SİYA, 624).

göğleme: Çocukların oynadıkları bir çeşit oyun (DS, 2131).

göverçin taklası: Çocukların birbirlerinin üzerinden atlayarak oynadıkları bir çeşit oyun (DS, 2169, AIIYA, 114).

göz yumuk [göz yumusu]: Körebe oyunu (DS, 2184).

gubba: Kaydirak oyunu (DS, 2186).

güvercin taklası: Arkaları birbirine dönük, elleri dizlerinde olarak eğilen dört çocuk üzerinden perende atarak geçilen bir çocuk oyunu (DS, 2241).

güzlenbeç: Saklambaç oyunu (DS, 2244).

halasu: Dört beş kişinin bir kişiyi ellerinde taşıyarak oynadıkları bir oyun (DS, 2257).

hamam kızdı: Bir çeşit çocuk oyunu (DS, 2263).

hampır: Çingene çocuklarının oynadığı bir çeşit oyun (DS, 2269).

harar: Bir çeşit saklambaç oyunu (DS, 2285).

haydur hoyma: Bir tür çocuk oyunu (BA, 900).

heççik: Beştaş oyunu (DS, 2326; SiYA, 633).

heligülü: Değnek, topaç ve kozakla oynanan bir çeşit çocuk oyunu (DS, 2333).

hellep: Beştaş oyunu (DS, 2336).

henhen oyunu: Bir çeşit şaşırtmaca oyunu (DS, 2340).

herlembe: Çocukların çamurla oynadıkları bir çeşit oyun (DS, 2347).

heşdik: Küçük taşlarla oynanan beştaş oyunu (DS, 2349).

heymafi: Birdirbir oyunu (DS, 2354).

hıd: Çocukların oynadıkları bir çeşit oyun (DS, 2357; SİYA, 634).

hıllik: Bir ceviz oyunu (TYAD, 175).

hıştut: Saklambaca benzeyen çocuk oyunu (DS, 2380). 
hilbili: Aşık oyunu (DS, 2384).

himan: Bir çeşit çocuk oyunu (GA, 242; GŞKA, 286).

himmet: Çelik çomak oyunu (DS, 4520).

hobbişli: Bir çeşit aşık oyunu (DS, 2390).

hoç: Koşmaca oyunu (DS, 2391).

hodak: Değnekle oynanan bir çeşit oyun (SIYYA, 363).

hohoy: Bir çeşit saklambaç oyunu (DS, 2395).

holhol [hol, höl höl]: Bir çeşit top oyunu (DS, 2396; AA, 1040; VHA, 842).

honaşık: Beştaş oyunu (DS, 2401).

hopbirtaş [hobba]: Beştaş oyunu (DS, 2405; SIYA, 636).

ḥor: Bilye veya taşla oynanan bir oyun (UMA, 261).

horom [horum]: Bir çeşit çocuk oyunu (DS, 2412).

hot [hot oyunu, hota, hotagaç]: Çocukların değnekle, kutu, yuvarlak taş ya da aşık büyüklüğünde bir ağaç parçasına vurarak oynadıkları oyun (DS, 2418; ÇA, 621; GA, 245; SIYA, 636; OAAD, 246).

hotdayak: Çubukla oynanan bir çeşit çocuk oyunu (DS, 2419).

höllük daş: Taşların üst üste yığılması ve üsttekinin düşürülmesine dayalı çocuk oyunu (SIYY, 637).

hölüş: 50-60 cm. uzunluğunda, ucu sivriltilmiş sopalarla oynanan bir çocuk oyunu (AA, 1040).

hömbek: Bir çocuk oyunu olup halka biçiminde oturan çocuklardan ikisi ortaya çıkarak bazı hareketler yaparlar. Halkadaki çocuklar da onları taklit ederler (DS, 2431).

höre: Onbeş yirmi santimetre boyundaki sopalarla oynanan bir çeşit oyun (DS, 2434; SIYA, 637).

hullu: Ağaç dalları üzerinde oynanan bir çeşit oyun (DS, 2442).

hulu: Değnekle oynanan bir çeşit oyun (DS, 2442). 
hüplemecek: Küçük çakıl taşı ya da findıkla oynanan bir çeşit çocuk oyunu (DS, 2451).

ığıllama: Bilye ya da mazıyla oynanan bir çeşit çocuk oyunu (DS, 2457).

ikilik: Bir çeşit aşı oyunu (DS, 2516; SiYA, 640).

ilkiççik: Bir çeşit çocuk oyunu ( DS, 2530).

illis: Saklambaç oyunu (DS, 2532).

incik: Bir çeşit çocuk oyunu, seksek, kaydırak (DS, 2539).

inne binne: Bir çeşit çocuk oyunu (DS, 2545).

ip içinde göz bağı: El ele tutuşarak bir daire oluşturan çocuklardan birinin gözlerinin bağlı olması suretiyle diğer çocukları yakalamaya çalıştığı bir çocuk oyunu (KRA, 163).

istop: Kiremit parçaları ve topla oynanan oyun (SIYYA, 641).

itti bitti: Saklambaç oyunu (DS, 2571).

kakbo: Gece oynanan saklambaç oyunu (DS, 2603).

kakkudaş: Beştaş oyunu (DS, 2605).

kankaz: Beştaş oyunu (DS, 2626; GA, 264).

kapçak: Çelik çomak oyunu (DS, 2632).

karaçepiş: Körebe oyunu (DS, 2642).

kaslankaba: Takla atılarak oynanan bir oyun (DS, 2676).

katın kırma: Bir çeşit aşık oyunu (DS, 2684).

kayanak: Yassı, kayıcı taşla oynanan bir oyun (DS, 2697).

kayataşı: Kaydırak oyunu (DS, 2699).

kazan: Bir çocuk oyunu (DS, 2711; SiYYA, 647).

kazankup: Topla oynanan bir çocuk oyunu (DS, 2712).

kazık [ġazık]: İnce uzun sopaları yere, çamura çakarak oynanan bir çocuk oyunu (DS, 4543; MA, 1227). 
kellem: Cevizle ya da taşla oynanan bir taş oyunu (DS, 2735).

kemicek: Aşık oyunu (DS, 2739).

kemig atmaca: Bir çocuk oyunu (AA, 1075).

kemiş oyunu: Aşık oyunu (DS, 2740).

keskelle: Birdirbir oyunu (DS, 2766).

kıbıdık: Çocukların hayvan tırnağı dikip taşla vurarak oynadıkları bir çeşit kaydırak oyunu (DS, 2782).

kıdım [kırıço]: Beştaş oyunu (DS, 2788; ÇA, 635).

kıfkıf̧̧ılık: Kovboyculuk adı da verilen Adıyaman yöresinde oynanan bir çocuk oyunu (AIYYA, 162).

k1lık: Cancan da denilen bir çocuk oyunu (DS, 2799).

kındak: Bilye ile oynanan bir çocuk oyunu (DS, 2809; SiYA, 652).

kıpçık: Vücut titretilerek oynanan bir oyun (DS, 2813).

ķırbaç: Kırbaçla oynanan bir çocuk oyunu (TYA, sz. 153).

ķırço: Çocukların oynadığı beştaş oyunu (VHA, 859).

kırkcık: Saklambaç oyunu (DS, 2830).

kit: Vurulmak üzere daha önceden toprağa dik bir biçimde gömülmüş nesnelerle veya misketle oynanan Adıyaman'a özgü bir çocuk oyunu (AİYA, 165).

kızgın taş: Karanlıkta yumruk büyüklüğünde bir gülle ile beşer kişilik gruplarla oynanan Adıyaman'a özgü bir oyun (AİYA, 166).

kibbi: Adıyaman yöresinde oynanan bir çocuk oyunu (AİYA, 166).

kinifi: Çelik çomak oyunu (DS, 2874).

kirpi: Taklite dayalı bir tür çocuk oyunu (KRA, 186).

kirtikli: Bir çeşit aşık oyunu (DS, 4563).

kişik: Satranç oyunu (DS, 2886).

kitüçilik: Saklanbaç oyunu (OTA, 146). 
koc: Ufak ve yuvarlak bir şeyi sopalarla vurarak ve yuvarlayarak oynanan bir çeşit oyun (DS, 2891).

konkoz: Beştaş oyunu (DS, 2919; GA, 279).

ķopça oyunu: Düğme ile oynanan bir çocuk oyunu (TYA, sz. 159).

ḳoşmaca: Bir tür çocuk oyunu (USA, 288).

koşum koşum: Tura ile oynanan bir çeşit çocuk oyunu (DS, 2935).

kotkot: Yumrukları üst üste koyarak oynanan bir çeşit oyun (DS, 2938).

kovalama: En az dört kişiyle oynanan bir çeşit çocuk oyunu (DS, 4569; USA, 288).

kozalak: Kozak ve değnekle oynanan bir çeşit oyun (DS, 2946; HAA, 394).

körçepiş: Körebe oyunu (KRA, 192).

kös: Toprak üzerindeki ufak çukurlara taşlar konarak, bir tarafı yuvarlak, bir tarafı düz olan dört değnekle oynanan bir çeşit oyun (DS, 2971).

kösmali: 20-25 cm. uzunluğundaki düzgün bir sopa ortadan ikiye bölünür ve her birinin üzerine beşer kertik yapılır. Havaya atılan bu sopaların ters ve yüz düşüşlerine göre ortada kalan kertikleri sayılarak oynanan eski bir oyun (DS, 2974).

köyelek: Körebe oyunu (DS, 2984).

ḳuḳa: Bir çocuk oyunu (AİAD, 271; SIYYA, 658).

kukupapula: Saklambaç oyunu (RİA, 325).

kulik: Bir çeşit misket oyunu (KRA, 195).

kupanca: Saklambaç oyunu (RİA, 325).

kuram: Dokuz taşla oynanan bir çocuk oyunu (DS, 3005).

ḳuzlanbaç: Bir çeşit çocuk oyunu (HAA, 394).

künd: Karş11ıklı ve kovalamaca biçiminde oynanan bir oyun (DS, 3037).

küsküç: Bir çeşit çocuk oyunu (DS, 4580).

küyüş: Bir çeşit çelik çomak oyunu (DS, 3057). 
lak: On sekiz taşla oynanan damaya benzer bir oyun (DS, 3060).

lame: Çocukların oynadığı çizgi oyunu (DS, 3063).

lapak oyunu: Topu duvara vurup düşürmeden yüze kadar sayarak oynanan oyun (DS, 3066).

lapaza: Kaydırak oyunu (DS, 3066).

lekdime oyunu: Yay biçimine getirilen değneklerin yere vurulup ileriye doğru firlatılmasiyla oynanan oyun (DS, 3071).

lekgele: Tek mi çift mi oyunu (DS, 3072).

lembeki: Çocukların yere çizdikleri çizgiler üzerinde ayaklarıyla seke seke bir düz taşı ittirerek oynadıkları çocuk oyunu (GA, 292).

lepik koko [leppik]: Çocukların yassı bir taşla kaleye diktikleri şeye vurarak oynadıkları oyun (DS, 3074; VHA, 870; VMA, 487).

loma: Çocukların oynadığı kuka oyunu (DS, 3086).

lop: Kuka oyunu (DS, 3087).

lopuh: Aşıkla oynanan oyun (DS, 3088).

löngür: Açılan çukura belirli bir yerden taş atılarak oynanan oyun (DS, 3093; KRA, 200).

madik: Bir çeşit bilye oyunu (DS, 3102).

mam: Çocukların oynadığı kaydırak oyunu (DS, 3115).

mamışık: Taşlarla oynanan bir çocuk oyunu (DS, 3116).

mazmaz: Çelik çomak oyunu (DS, 3147).

meliķan: Bir tür çelik çomak oyunu (VHA, 874; VMA, 890).

mendik: Beş taşla Adıyaman yöresinde oynanan bir oyun (AİYA, 190).

mercik: Adıyaman yöresinde taşla oynanan bir oyun (AİYA, 190).

mesmes: Kaleye konulan taşa, taş ya da değnekle vurarak oynanan çocuk oyunu (DS, 3173).

meşek: Yassı taşla oynanan kaydırak oyunu (DS, 3174). 
meşmel: Bir çeşit aşık oyunu (SiYA, 666).

met [met değnek]: Çelik çomak oyunu (DS, 4595; AA, 1107; BA, 915; ÇA, 646; EYA, 725; KDA, 446; AMA, 314; RİA, 327; SIYA, 666; OAAD, 251).

mıçı: Ortaya konulan para ya da bilyeye, kayrak taşlarıyla vurarak oynanan bir çocuk oyunu (DS, 3179).

mıh: Topaç, döndürek oyunu (DS, 3181).

mırık: 1. Hayvan tırnağıyla oynanan bir çeşit çocuk oyunu. 2. Topaç oyunu. 3. Yassı taşlarla oynanan bir çocuk oyunu (DS, 3188; ÇA, 647).

milā [milli]: Çocukların oynadığı çelik çomak oyunu (DS, 3199).

miras: Bilye oyunu (RİA, 327).

mire [mirre]: Aşık oyununun bir çeşidi (DS, 3203; KYA, 489).

mişilli: Taşla oynanan bir çeşit oyun (IEA, 381).

mit: Çelik çomak oyunu (DS, 3205).

mocuk: Çukura taş atarak oynanan bir çocuk oyunu (DS, 3207).

moç: Topuzlu sopalarla oynanan bir çeşit oyun (DS, 3208).

mulavara: Saklambaç oyunu (DS, 3219).

mumuk: Körebe oyunu (BRA, 158).

muncığa gömen: Çocukların toprakta boncuk saklayıp bularak oynadıkları bir çeşit oyun (DS, 3220).

murt: Taşlarla oynanan bir çocuk oyunu (DS, 3222).

nalbir: Düz ve yassı taşlarla oynanan kaydırak oyunu (DS, 3236).

naldırnaç: Çelik çomak oyunu (DS, 4604; ÇA, 648; GA, 312; SiYA, 669).

nillime: Kaydırak oyunu (DS, 3252).

ondi dumana bindi: Topla oynanan bir çocuk oyunu (DS, 4616).

ophan: Bir çocuk oyunu adı (KYA, 491). 
oyuktaşı: Üç-beş kişiden oluşan iki topluluğun $20 \mathrm{~m}$. aralıklarla üç yere dikilmiş taşları devirerek oynadıkları bir çeşit oyun (DS, 4620).

ödek: Çanak biçimindeki çamuru taşa vurup patlatarak oynanan bir çocuk oyunu (DS, 3312).

ökğel: Bir çeşit taş oyunu (DS, 4624).

papara: Top, belirtilen çukura düşürülerek oynanan bir çeşit oyun (DS, 4637).

parmaklarım: Daire olan oyunculardan birinin dairenin ortasına geçmesi ve diğerlerinin onun söyleyeceklerini tekrarlamasıyla oynanan bir oyun (KRA, 221).

paşaçömlek: Kızların oturdukları yerde oynadıkları bir oyun (DS, 3408).

pat1: Körebe oyunu (DS, 3411).

patlangoç: Çamurla oynanan bir tür çocuk oyunu (GA, 326).

paya: Seksek oyunu (DS, 4642).

pelden: Kaydirak oyunu (DS, 3424).

pempez: Küçük, yuvarlak taşlarla oynanan bir çocuk oyunu (DS, 3427).

pırık: Adıyaman’a özgü bir çocuk oyunu (AİYA, 220).

pirebolu: Bir çeşit çocuk oyunu (AA, 1180).

puka: Kaydirak oyunu (DS, 3486).

rez: Sert bir zemin üzerine çizilen çizgiler üzerinde taş ya da cam parçalarıyla oynanan bir çocuk oyunu (VMA, 501).

saban monduruh: Bir çeşit çocuk oyunu (GA, 336; GŞKA, 289).

sāfi: Bir tür çocuk oyunu (BA, 928).

saklambacık: Saklambaç oyunu (DS, 4665).

saklangıç oyunu [saḩlanpertik]: Saklambaç oyunu (DS, 3522).

salmaç: Bir çeşit çelik çomak oyunu (DS, 4669).

sekir: Bir çeşit yüzük oyunu (DS, 4681).

sekmedikme: Çocukların ince sopalarla oynadıkları bir çeşit oyun (DS, 4682). 
sekmen: Tek ayak üstünde yürüme, seksek (SIYY, 684).

sektekkiç: Çocukların karşı1ıklı geçip bir ayaküstünde sıçrayarak oynadıkları oyun (DS, 3575).

seḳtilemeç: Bir çocuk oyunu adı (OAAD, 257).

seykir: Yüzük oyunu (DS, 3600).

sinır: Kaydirak oyunu (DS, 3614).

siraman: Birdirbir oyunu (DS, 3616).

siğlenbörüt: Saklambaç oyunu (SIYYA, 687).

silgeç: Bir çeşit çocuk oyunu, birdirbir (DS, 3635).

simi: El ele tutuşarak seke seke oynanan bir çocuk oyunu (DS, 3638).

sinenbeç [simmeç, señnenmeç, siğnebit, siğnebitti, siğnenmeç, sin, sinebidik, sinebit, sinembitti, sinenbeç, sinenbitti, sinenmeç, sinlenbeç, sinlenbiç, sinmece, siñmeceğ, sinmecek, sinmecik, sinmemmeç, sinneci, sinnenbeç, siñnengeç, sinnenbözü, sinnenmece, sinnenmeç]: Saklambaç oyunu (DS, 3642; AYA, 840; GGA, 282; GA, 347; SIYA, 687).

sinmece: Saklambaç oyunu (TYA, sz. 211).

siviştir: Mendil saklanarak oynanan bir çeşit oyun (DS, 3651).

siylenbicik: Saklambaç oyunu (SIYYA, 687).

somanak: Ucu sivri sopalarla oynanan bir çeşit oyun (sopalar yere saplanır, yenilen sopasını sökerken karşısındaki sayı alır) (DS, 4704).

sormah: Bir çeşit aşık oyunu (DS, 3667).

söbe [söbem]: Saklambaç oyunu (DS, 4706; MA, 1246).

sual: Bir çeşit çocuk oyunu (Ebe kalede bekler, öteki çocuklar saklanır, ebe gördüklerinin adlarını elindeki taşı kaleye vurarak söyler.) (DS, 3688).

sultan: Bir çeşit aşık oyunu (KAKD, 396).

süldür: Çelik çomak oyunu (DS, 3709).

sülenke: Bir çeşit kaydırak oyunu (DS, 3709). 
süzdürmeç: İnce değneklerle oynanan oyun (DS, 3732).

şapş1: Bir tür çocuk oyunu (BA, 934).

şırşır: Bir tür çocuk oyunu (EİA, 266).

taklavık: Çocukların kamış ya da mürver dalı içerisine kıtık sokup çöple iterek oynadıkları bir çeşit oyun (DS, 3812).

tappır: Beştaş oyunu (DS, 3830).

taskalla: Kemikle oynanan bir çeşit oyun (DS, 3839).

taşçakma: Körebe oyunu (DS, 3841).

tavşankaç: Bir çeşit çocuk oyunu (DS, 3850).

tekmekayrak: Kaydırak da denilen bir çeşit oyun (DS, 3868).

tektirme: Esnek çubuklarla oynanan bir çeşit oyun (DS, 4750).

temel: Bir çeşit tura oyunu (DS, 3877).

tenten: Bir çeşit çocuk oyunu (DS, 4754).

tıkırcın: Dokuztaş oyunu (DS, 4760).

tılıs: Bir çeşit çocuk oyunu (DS, 4760; GA, 371).

tımırlama: Çelik çomak oyununda erken bitiren oyuncunun bitiremeyen oyuncuyu bitirinceye kadar oyalamak için oynadığı Adıyaman'a özgü bir çocuk oyunu (AİYA, 260).

tımırlek: Çelik çomak oyununa Adıyaman yöresinde verilen ad (AİYA, 263).

toka: Bir tür çocuk oyunu (BA, 940).

tokula [tokalan]: Değnekle yuvarlak taşa vurarak oynanan bir çocuk oyunu (DS, 3952, 4767).

tokurcun: Dokuztaş oyunu (DS, 4768).

tolaka: 1. Parayla oynanan yazı tura oyunu. 2. Mendil ucu düğümlenerek oynanan bir çeşit oyun (DS, 3954).

tombik: Bir tür çocuk oyunu (BA, 940). 
tombili: Taş ve kiremitle oynanan bir çocuk oyunu (KRA, 261).

topagaran: Koyun yününden yapılan topla oynanan beyzbol tarzında bir oyun (VHA, 913).

tos: Topaç oyunu (DS, 3972).

toskellef oyunu: Değnekle tahta parçalarına vurularak oynanan bir çeşit oyun (DS, 4772).

tot: Hokey oyunu gibi değnekle taşa vurularak oynanan bir oyun (DS, 3976).

totuk: Bir çeşit çocuk oyunu (DS, 3976).

tula oyunu: Mendil bağlayıp birinin arkasına bırakılarak oynanan bir çeşit çocuk oyunu (DS, 4776; GA, 376).

tulġara: Bir çeşit çocuk oyunu (GA, 375; GŞKA, 290).

tuşobe: Saklambaç oyunu (SIYA, 702).

tümpeti: Beştaş oyunu (DS, 4013).

türşek: Kaydırak oyunu (DS, 4016).

uçdan [uçtan]: İnce ve uzunca bir değneği yere çarparak atmak yoluyla oynanan bir oyun (DS, 4023).

ust: Koşturmaca oyunu (RİA, 335).

uzunumeşşek: Birdirbir (DS, 4056).

üçdaş oyunu [üşdaş, üçleme, üçnişan, üçtaş oyunu]: Bir eşkenar dörtgenin dörde bölen çizgilerin kesişme noktaları üstüne çakıl taşı konularak karşılık oynanan oyun (DS, 4057; BA, 944).

ümmet: Çelik çomak oyunu (MA, 1250).

üz: Dokuztaş oyunu (DS, 4800; GA, 383).

vizdırak: Kaydırak oyunu (DS, 4014).

vız vız [vızıldak]: Bir düğmenin iki deliğinden iplik geçirip esnete esnete döndürülerek oynanan bir oyun (DS, 4105).

vız vız tula: Mendille oynanan bir çeşit çocuk oyunu (DS, 4807; GA, 386). 
yangınalayı: Sıraya dizilip ip atlama (çocuk oyunu) (DS, 4168).

yavrulutavuk: Yerlere çukur kazarak topla oynanan bir çocuk oyunu (DS, 4208).

yeldürme: Baş örtüsü ve değneklerle oynanan bir çocuk oyunu (GA, 397).

yemlekasma: Bir çocuk oyunu (DS, 4244).

yıkık: Üst üste taşlar konulup yıkılarak oynanan bir çocuk oyunu (DS, 4265).

yumbaç [yumkaç]: Saklambaç (DS, 4317).

yumulmaç [yumuçma, yumulgaç]: Saklambaç (DS, 4319).

yuvalamaca: Ceviz oyunu (DS, 4326).

yütük oyunu: Saklambaç (ÇA, 688).

yüzlük: Bir çocuk oyunu (DS, 4339).

yüzüh turası: Yüzük ve sopayla oynanan bir çocuk oyunu (GA, 404; GŞKA, 291).

yüzük oyunu: Kışın evde oynanan bir oyun (DS, 4340; SİYA, 718).

zalaga: İnce değnekleri yere vurup yaylandırarak oynanan bir oyun (DS, 4347; KRA, 289).

zeze: Bir oyun çeşidi (DS, 4366).

zıbbaḳ: Bir çocuk oyunu (MYA, 472).

zıḳka: Bir çocuk oyunu (KYA, 505).

zıldırzıp: Bir tür çocuk oyunu (GGA, 292).

zımba: Bir çeşit çocuk oyunu (DS, 4837).

zıng: Üçtaş, dokuztaş gibi oyunların genel adı (DS, 4373).

zıvaylık: Yere dikilmiş bir ağaç üstüne yatay olarak konulan bir başka ağaçla oynanan çocuk oyunu (DS, 4384).

zimi: Soğuk günlerde çocukların sekerek oynadıkları bir oyun (DS, 4840).

zimit: Çocukların arasında oynanan bir oyunun adı (MA, 1254).

zipzop: Düdük çıkarma oyunu (DS, 4391). 
ziraman: Koşmaca oyunu (DS, 4391).

zivziv: Tura oyunu (DS, 4393).

\section{Türkiye Türkçesi Ağızlarında Halk Oyunları}

ağır tikveş: Tikveş bölgesinden göç eden muhacirlerin oynadığı bir tür halk oyunu (KRA, 46).

ağırlama: Adıyaman'a has halk oyunlarından biri ((AİYA, 7).

akdara: Erkekler tarafindan oynanan bir oyun (DS, 146).

alay: Genellikle davul zurna eşliğinde toplu olarak oynanan bir tür halk oyunu (KRA, 51).

alay turas1: Dügünlerde oynanan bir oyun (KA, 547).

Ali Paşa: Drama, Zigoş ve Zarıç göçmenlerinin oynadıkları bir tür halk oyunu (KRA, 51).

alika: Bir horon çeşidi (RİA, 310).

altı ayaķlı atlama: En hızlı oynanan horan oyunlarından biri (TYA, sz. 12).

anergi: Adıyaman yöresine özgü bir oyun (AİYA, 13).

anẓer: Bir horon çeşidi (RİA, 310).

atalık: Düğün haftasının Perşembe sabahı şafak sökerken aile halkının ve yakınlarının davul zurna ile oynadıkları oyun (DS, 365).

atlama: Erkekler tarafindan daire veya sıralanma biçiminde oynanan horan (TYA, sz. 20).

bar: El ele tutuşarak, halka şeklinde oynanan bir millî oyun (DS, 523; GA, 39).

barış oyunu: Adıyaman'a özgü bir folklor oyunu (AİYA, 23).

bengi: Hareketli bir zeybek oyunu (DS, 628).

beş ayak: Adıyaman yöresine özgü bir folklor oyunu (AİYA, 28).

beymisa: Doyran ve Kılışlıların oynadıkları bir tür halk oyunu (KRA, 78).

börülce: Düğünlerde erkeklerin oynadıkları hareketli balkan ezgilerine sahip bir oyun (KRA, 84). 
ceylan: Yalnız bir erkek tarafindan oynanan halk oyunu (DS, 887).

c1zık: Davul, zurna ile oynanan bir çeşit oyun (DS, 949).

çamur döken: Adıyaman'a özgü halk oyunlarından biri (AİYA, 48).

çift ayak: Bir Urfa oyunu (DS, 1205).

dallıke: Grup hâlinde oynanan halay gibi ve çok hareketli bir oyun (DS, 1346).

darabul: Köy dügünlerinde geceleri, ateş etrafinda, davul, zurna ile oynanan oyun (DS, 1365).

delilo: Bir tür halk oyunu (VHA, 809).

depki: Halay (DS, 1430).

dere bek: Oldukça ağır oynanan Kastamonu halk oyunlarından biri (AAT, 214).

deve düzülme: Köy düğünlerinde oynanan eski bir oyun (AŞA, 382).

dillan: Geleneksel bir halk oyunu, halay (GİAT, 273).

dipçik: Düğünlerde şarkı söyleyerek oynanan bir halk oyunu (DS, 1510).

diringi: Erkekler tarafindan oynanan bir kişilik halk oyunu (DS, 1517).

doldala: Bir çeşit bar oyunu (DS, 1546).

domuzu bataktan çıkarma: Kırklareli yöresinde oynanan bir halk oyunu (KRA, 119).

enzeli: Kadın ve erkek tarafından karşılıklı oynanan bir halk oyunu (DS, 1762).

esir almaca: Dügünlerde oynanan bir halk dansı (DS, 1782).

eski kasap: Erkeklerin sol kol önden sağ kol arkadan gelecek şekilde omuzdan bağlanarak oynadıkları, izlemesi ve oynaması çok zevkli olan hora sınıfina müdahil bir oyun (KRA, 133).

eşbulma: Toplantılarda oynanan bir halk oyunu (DS, 1788).

garşılama [karşılama]: Bir halk oyunu türü (BİA, 677; GGA, 272; KRA, 174).

goftan: Adıyaman'ın yöresel halk oyunlarından biri (AİYA, 106).

göçeri: Adıyaman'ın yöresel halk oyunlarından biri (AIYYA, 108). 
gövenk: Kadın ve erkeklerin beraber oynadıkları bir bar oyunu (VHA, 830).

haley [aley]: Davul zurna eşliğinde oynanan halk oyunu, halay (KYA, 481; GíAT, 262).

ḥalķum: El ele tutuşup halka biçimine gelerek oynanan horan oyunu (TYA, sz. 115).

hallaç oyunu: Adıyaman yöresinde oynanan bir halk oyunu (AİYA, 117).

hanayı hanay: Bir çeşit oyun, horan (DS, 2271; SiYA, 630).

hançal barı: Bir kişinin iki bıçakla oynadığı oyun (DS, 2272).

hanım Ayşe: Göçler sırasında Batı Trakya'dan gelen göçmenler vasıtasıyla getirilmiş, kızlı erkekli oynanan bir halk oyunu (KRA, 151).

hasandağı: Bir çeşit çiftetelli oyunu (DS, 2297).

hasat: Adıyaman yöresine özgü bir halk oyunu (AİYA, 121).

hemşin: Bir horon çeşidi (RİA, 319).

heng: Folklorik bir oyun (BSA, 403).

herzani: Bir tür halk oyunu (VHA, 838).

horan [hora, horam, horon]: El ele tutuşarak halka şeklinde oynanan bir çeşit oyun (DS, 2408; GA, 245; GŞKA, 285; RİA, 320; TYA, sz. 121; KİAT, 329).

horuz: Hanımların tek başlarına oynadıkları bir çeşit dans (DS, 2415).

hoşbilezik: Bir çeşit bar oyunu (DS, 2416).

hoy maval: Bir çeşit bar oyunu (DS, 2422).

ḥozangel: Daha çok Akçaabat yöresinde oynanan horan türü (TYA, sz. 123).

İbrahim Hoca: Kırklareli yöresinde oynanan bir tür halk oyunu (KRA, 160).

iki ayak: Bir horon çeşidi (RİA, 321).

istemey: Kızlı erkekli oynanan bir folklor oyunu (DS, 2561).

kadı: Bir halk oyunu (DS, 2591).

kadıoğlu: Bir halk oyunu (DS, 2591). 
kaftan oyunu: Adıyaman yöresine ait bir halk oyunu (AİYA, 149).

kalayc1: Bir halk oyunu (DS, 2610).

kampana: Oyuncuların serçe parmaklarıyla birbirlerine bağlanarak oynadıkları bir tür halay (KRA, 170).

karabağ: Tek ya da iki kişiyle oynanan bir halk oyunu (DS, 2638).

karsınönü: Bir çeşit halk oyunu, bar (DS, 2670).

kasap havası: Zurna veya klarnetin çaldığı, melodi ve davulun temposuyla Kırklareli yöresinde oynanan bir tür halk oyunu (KRA, 174).

kaynana oyunu: Adiyaman yöresine ait bir halk oyunu (AİYA, 155).

kenek: Tek kadının oynadığı bir halk oyunu (DS, 2743).

kımıl oyunu: Adıyaman yöresine ait bir halk oyunu (AİYA, 163).

kırk haydut: Oyuncuların birbirlerinin serçe parmaklarından tuttukları ve dört ritimle sağa ve sola gidip geldikleri bir oyun (KRA, 182).

kocaarap: Tek kişinin oynadığı bir halk oyunu (DS, 2891).

koçar1 [ķoççar1]: Bir çeşit bar oyunu (DS, 2895; VHA, 862).

ķuvang: Kadın ve erkeklerin beraber oynadıkları bir tür bar oyunu (VHA, 867).

küçük molla: Kırklareli yöresinde oynanan bir halk oyunu (KRA, 197).

laçin: Bir tür halk oyunu (VHA, 869).

lezgi: Erkek, kadın karışık oynanan bir halk oyunu (DS, 3076).

lorke: Bir tür halk oyunu (USA, 289).

memetina: Bir horon çeşidi (RİA, 326).

meşeli: Bir çeşit halk oyunu (DS, 4595).

nanay: Düğünlerde çalgısız olarak türküyle oynanan bir halk oyunu (DS, 3239).

nari: Bir halk oyunu, bar (DS, 3241).

ortacala: Bir çeşit halk oyunu, bar (DS, 3290). 
osmanlı: İki erkek bir kadınla oynanan halk oyunu (DS, 3293).

öndört: Kadınlarla erkeklerin birlikte oynadıkları bir halk oyunu (DS, 3338).

ördek: Tek kadının oynadığı bir halk oyunu (DS, 3346).

pancar havası: Kırklareli yöresinde oynanan bir tür halk oyunu (KRA, 220).

papila: Bir horon çeşidi (RİA, 329).

papiri: Bir kişinin oynadığı halk oyunu (DS, 3395).

papuççitir: Bir halk oyunu (DS, 3396; SIYA, 676).

patrona: Arnavutluk göçmenlerinin oynadıkları bir tür halk oyunu (KRA, 223).

pavle: Karacaova göçmenlerinin oynadığı bir tür halk oyunu (KRA, 223).

pehlivanlık oyunu: Kırklareli yöresinde oynanan taklide dayalı bir halk oyunu (KRA, 224).

pişik: Tek kadın tarafindan oynanan bir halk oyunu (DS, 3464).

rampi: Kırklareli yöresinde oynanan bir tür halk oyunu (KRA, 229).

Rize: Bir horon çeşidi (RİA, 330).

Rum kızı: Kırklareli yöresinde oynanan bir tür halk oyunu (KRA, 230).

sal oyunu: Adıyaman yöresine özgü halk oyunlarından biri (AİYA, 231).

sallama: Bir çeşit oyun, horan (DS, 4668; GA, 338; TYA, sz. 204).

șano: Bir horon çeşidi (RİA, 332).

sarhoşbarı: Bir çeşit bar, halk oyunu (DS, 3546).

șarişka: Bir horon çeşidi (RİA, 332).

seğmen [seman]: Ege'de erkekler tarafından oynanan bir çeşit halk oyunu (MAA, 296; MA, 1244).

sekme: Erzurum bar1, bir halk oyunu (GA, 342).

Selanik: Kırklareli yöresinde oynanan bir tür halk oyunu (KRA, 235). 
semah: Alevî çevrelerinde halk musikisi eşliğinde oynanan dinî menşeli oyun (MİA, 417).

senem: Kadın ve erkeklerin karşılıklı oynadıkları bir halk oyunu (DS, 3583).

sevdican: Kadın ve erkeklerin birlikte oynadıkları bir halk oyunu (DS, 3595).

sihssaray [sık̨ sara]: Bir horon çeşidi (RİA, 332; TYA, sz. 210).

solak oyunu: Adıyaman yöresi halk oyunlarından biri (AİYA, 241).

sürükleme: Düğünlerde oynanan bir çeşit oyun (DS, 3725).

sürütme: Bir çeşit halk oyunu (DS, 4717; GA, 353).

süsensünbül: Tek kadının oynadığı bir halk oyunu (DS, 3727).

şemmame: Bir tür halk oyunu (VHA, 902).

şololu: Düğün ve şenliklerde erkelerin oynadıkları bir oyun (DS, 3792).

tarabul: Bir çeşit halk oyunu (DS, 3833).

tekoyon: Bir kişinin oynadığı bir çeşit zeybek (DS, 3869).

tellice: Tek kadının oynadığı bir halk oyunu (DS, 3874).

terlik oyunu: Kadınların oynadığı bir çeşit halk oyunu (DS, 3895).

terşi: Adıyaman yöresine özgü geleneksel bir oyun (AİYA, 261).

toska: Arnavut göçmenlerinin oynadıkları bir tür halk oyunu (KRA, 262).

toycilar: Van yöresinde oynanan bir halk oyunu (VMA, 514).

tutu: El ele tutuşarak oynanan bir halk oyunu, halay (DS, 4003).

türkan oyunu: Adıyaman yöresinde oynanan bir halk oyunu (AİYA, 270).

urumtiki: Bir çeşit horan (DS, 4788).

üçayak [üçayakl1]: Bir çeşit horon (DS, 4057; SiYA, 705).

yallı: Halay oyunu (KİA, 385).

zigoş: Batı Trakya Türklerinin kızlı erkekli oynadığı hareketli bir halk oyunu (KRA, 291). 


\section{Türkiye Türkçesi Ağızlarında Diğer Oyun Adları}

akdört: 7-8 cm. uzunluğunda dört ağaç parçasıyla oynanan bir ev oyunu (DS, 148).

akka dukka: Bir çeşit oyun (DS, 155).

aklın fikrin var mı: Sandalyeye çıkan kadına topluluk tarafından sorulan eğlenceli sorularla oynanan bir oyun (KRA, 49).

alabacak: Bir kişinin değnekle, koşarak oynadığı bir çeşit oyun (DS, 172).

almaçlı [almalı]: Yenilen kimsenin ortaya koyduğu şeyi (para, bilye, aşık vb.), yenen kimsenin alıp kendisine mal etmesi şart koşulmuş olan oyun (DS, 227; GA, 17; SIYA, 555).

altı gol: Altı kişiyle oynanan bir kağıt oyunu (KDA, 425).

Arap oyunu [Araboyunu]: Düğünlerde büyükler tarafından oynanan eğlenceli bir oyun (DS, 299; EYA, 542; MSA, 702).

araskesme [ara kesdirmesi]: Gençler arasında oynanan bir oyun (DS, 300; AA, 691; MA, 1210).

aşşuh sekme: Kına gecelerinde erkeklerin oynadığı bir çeşit oyun (GA, 28; GŞKA, 281).

atlı deynek: Cirit oyunu (KYA, 462).

avul oyunu: Eşit sayıdaki iki gruba ayrılan oyuncular tarafından oynanan dıştaki oyuncunun içerdekileri vurmayı amaçladığı oyun (KRA, 63).

ayıcı oyunu: Bir kişiyi ayı kılığına sokarak oynanan bir kış oyunu (DS, 416).

Ayşe abat: En az 5 metre uzağa dikilen parayı cevizle vurma oyunu (DS, 431; SiYA, 562).

aznif oyunu: Kahvehanelerde oynanan Adıyaman'a özgü bir oyun (AİYA, 20).

barkut: Zarla oynanan bir çeşit oyun (DS, 534).

basara: İskambil kâğıdı ile oynanan ve pişti de denilen oyun (DS, 538).

basıra [basma]: Bir çeşit kâğıt oyunu (DS, 541).

basma [basmaca]: İskambil kâğıdı ile oynanan bir oyun (DS, 544). 
basra: Bir çeşit kâğıt oyunu (DS, 545).

batıbar: Kızlar arasında oynanan bir oyun (Su başında toplanan kızlar, suyla dolu bir kabın içine çiçek atıp kaderlerine bakarlar. Sonra da birbirlerine su atarak oynarlar.) (DS, 570).

bebek: Tek kadın tarafindan oynanan bir oyun (DS, 590).

beşaçılan: Bir erkek tarafından oynanan oyun (DS, 642).

bıçak oyunu: Büyük bıçaklarla, iki kişi tarafından, yapmacık saldırışlarla oynanan oyun (DS, 655; TYA, sz. 35).

bicek: Hidırellez günü oynanan mâni ile yüzük çekme oyunu (DS, 679; VHA, 792).

buk kubbezi: Gelin kaçırma adı da verilen, oyunu oynayan kişiler arasında seçilen gelinin etrafindaki dairenin ortasında durup onu kaçıracak oyunculardan korunması şeklinde oynanan Adıyaman'a özgü bir oyun (AİYA, 36).

crrıt [cirit, crrıt oyunu]: At üstünde değnekle oynanan oyun (DS, 931; AA, 788; GŞKA, 282; MİA, 392; SIYYA, 578; UİA, 373).

cıvgar: Güreşçinin rakibini yenmek için yaptığı oyun (DS, 942).

cimdallı: Hareketli bir kadın oyunu (DS, 972).

cizek: Bir oyun adı (DS, 991).

cop oyunu [cop galgıtma]: Bir çeşit cirit oyunu (DS, 1000; UİA, 373).

çakmaca: Bozuk parayla oynanan bir kumar oyunu (DS, 1045).

çaltayak: Güreşte yapılan bir oyun (DS, 1062).

çangal [çañğal, çankal]: Güreşte bir ayak oyunu, çelme takma (DS, 1070).

çarık kapmaca: Bir çeşit oyun (DS, 1081).

çevrim: Dügünlerde geceleri meşale yakıp etrafına toplanarak oynanan oyun (DS, 1154).

çıldırgeç: Gece ay ışı̆̆ında oynanan bir oyun (DS, 1172).

çındır: Sinsin denilen oyun (DS, 1179).

çiftyümbek: Yetişkinlerin oynadıkları bir çeşit oyun (DS, 4481). 
çombala: Kağıt oyunu (DS, 1265).

çur: Bir çeşit oyun (DS, 1305).

dabıl: Tek kişi ile oynanan masa tenisi (DS, 1315).

değnek: Cirit oyunu (DS, 1403).

denem beşe: Köy odalarında iki zar ya da aşıkla oynanan bir oyundur. İki kişi karşılıklı oturup ellerine ceviz, findık gibi yemiş ya da ufak para alırlar. Biri elinde tuttuğuna at der, atılan zarlar aynı (dört dört, altı altı gibi) aşık bey tarafına gelirse, karşıdakinin elinde tuttukları onun olur. Zarlar ya da aşık uygun düşmezse elindekileri verir. Oyunun en kızışıı̆ı zaman zarı atana karşıdaki "denem beşe" der. Zarı atanın zarları ya da aşık uygun düşerse bire beş verir, uygun düşmezse bire beş alır.

dibek: İkişerli gruplar hâlinde oynanan Adıyaman'a özgü geleneksel bir oyun (AIYA, 67).

enjuro: Yetişkinlerin oynadıkları bir tür oyun (USA, 283).

esnek: Pehlivanların çene altından parmakları ile birbirlerini boğarcasına yaptıkları oyun (DS, 1786; SIYYA, 607).

gara zelve: Güreşte bir oyun (OAA, 132).

garış guruş: Bir oyun adı (DS, 1927).

göz sahlama: Bir tür oyun (USA, 284).

guramanıç: Üç kişiyle oynanan bir oyun (DS, 4514).

güce: Bir çeşit oyun (DS, 2207).

hımbıl: Bir çeşit iskambil oyunu (DS, 2361).

hicip: Delikanlıların yüzük ve aşıklarla oynadıkları bir çeşit oyun (DS, 2383).

himmek: Adıyaman yöresinde oynanan eski bir oyuna verilen ad (AİYA, 133).

hümbek: En az üç kişi ile ve mendille oynanan Adıyaman'a özgü bir oyun (AİYA, 137).

ilk kocam oyunu: Genellikle kına gecesinde oynanan, kadın ve kızların bir araya toplanarak iki kadının yüzlerini çemberle örterek birinin kadın diğerinin koca şekline girmesiyle oynanan bir oyun (KRA, 162). 
kadal: Cirit oyunu (DS, 2589).

karalama: Adıyaman yöresine ait bir seyirlik oyuna verilen ad (AIYYA, 153).

karazelve: Güreşte kolbastı denilen oyun (DS, 2656; SiYA, 645).

kıç dingili: Kara güreşte kalçanın yardımıyla yapılan kafa, kol oyunu (SİYA, 651).

kılıç çekme: İskambil kağıdı ile oynanan bir çeşit oyun (KRA, 181).

kolbastı: Güreşte bir oyun (DS, 4566; SİYA, 655).

ḳolçi ḳaçahçi: Bir tür oyun (USA, 288).

kon kon oyunu: Macun tahtasına para koyarak oynanan bir çeşit oyun (DS, 2919).

küdü: Adıyaman yöresinde bireysel oynanan geleneksel bir oyun (AİYA, 175).

künte: Güreşçilerin güreşte kullandıkları bir çeşit oyun (DS, 3040).

lo: Ağır bir loğu deliklerinden tutarak oynanan Adıyaman'a özgü bir oyun (AIYYA, 181).

lofloḳo: Bir tür oyun (EYAD, 236).

mahdüver: Hıdrellez gecesi hazırlanan ve sabah çekilen kısmet oyunu (DS, 3106).

mantıfal: Kutu içine konan çiçekleri çekerek mani okuma (bir çeşit oyun) (DS, 4588; KRA, 202).

mentivar: Gece toplantılarında kadınların oynadığı bir oyun (DS, 3166).

mert çıbuh: Yetişkinlerin oynadıkları bir tür oyun (USA, 290).

pabıç: Çarpmaca da denilen ve ikiden fazla kişinin ellerindeki terliklerle diğer oyunculara vurmaya çalıştığı Adıyaman'a özgü bir oyun (AİYA, 215).

peket: Kağıt oyunlarına verilen genel ad (KYA, 493).

rıḳıım: Adıyaman'a özgü bir tür oyun (AİYA, 227).

semet: Dügünde oynanan yumurta oyunu (DS, 3582).

simsim: Ateşin çevresinde oynanan bir oyun (DS, 3639). 
sinsin [siñsiñ, sīnsīn]: Gece ateş çevresinde oynanan bir çeşit oyun (DS; 3646; AİYA, 239; AA, 1209; ÇA, 661; MİA, 418; SİYA, 687).

suñsuñ: Düğünlerde ateş çevresinde dönülerek oynanan oyun (DS, 3699).

şıldır [şıldır şıp]: Köylerde, gençlerin oynadığı bir çeşit mendil oyunu (DS, 3770; AİYA, 251; KRA, 248).

şildirip: Birisinin komutuyla yatıp kalkılarak oynanan bir çeşit oyun (DS, 3779).

tabla: Tavla (zarla oynanan oyun) (DS, 4733).

tabya kapmaca: Daire olan oyunculardan birinin dairenin ortasına geçip tekerlemeler söyleyerek oynadıkları oyun (KRA, 252).

tekyümbek: Bir çeşit oyun (DS, 4750).

tellik: Bir çeşit oyun (DS, 3874).

tırıng1: Tek başına oynanan bir çeşit oyun (DS, 3922).

tonç: Bir çeşit iskambil oyunu (DS, 3961).

tura: Düğümlenmiş mendille erkeklerin düğünlerde oynadıkları, güce ve vurmaya dayal1 sert bir oyun (AİYA, 269; MİA, 421).

tünge: Bir çeşit milli oyun (DS, 4013).

uçayak: Bir çeşit oyun (DS, 4782).

yarımsarma: Güreşte alttan kurtulmak için başvurulan etkili bir oyun (DS, 4187; SIYA, 711).

yastıktaklası: Gençlerin oynadığı bir oyun (DS, 4198).

yumuşacık: Kadınların nitelikleri değişik nesneleri bir örtü altından elden ele geçirerek oynadıkları eğlenceli bir ev oyunu (DS, 4320).

\section{SONUÇ}

Türkiye Türkçesi ağızlarındaki çocuk oyunları, halk oyunları ve diğer oyun adları şeklinde üç başlık altında toplanan bu çalışmada 577 çocuk oyunu, 138 halk oyunu ve 106 diğer oyun adı tespit edilmiştir. Türkiye Türkçesi ağızlarında varlığını devam ettiren bu oyun adlarından müstakil kelime ya da kelime grubu özelliği taşıyanlar tercih edilmiş, aynı kelimenin farklı söyleyiş şekillerine çalışmada yer verilmemiştir. 
Türkiye Türkçesi ağızlarında en fazla "saklambaç” oyununun karşılığı olarak kullanılan kelime ya da kelime grupları tespit edilmiştir (31 adet). Bu çalışmada toplam 821 oyun adı tespit edilmiştir. Bu oyun adlarından sadece 23 tanesine Türkçe Sözlük'te yer verilmiştir. (ăğrlama, ayıcı oyunu, 'aznif oyunu, bar, bengi, cirit, cimdall, çangal, çelik çomak, dokurcun, fanti, karşılama, horon, kolbast,, koşmaca, künte 'künde', madik, met, semah, sinsin, tellice, tokurcun, tura, ).

Türkiye Türkçesi ağızlarındaki oyun adlarından büyük bir bölümü Türkçenin morfolojik özelliklerine uygun bir biçimde oluşturulmamıştır. Dolayısıyla bu adların büyük bir bölümü rastgele oluşturulmuş izlenimi uyandırmaktadır (alda, arıdız, bır, bucuk, caynız, cibide, çıllık, çöttük, dız, dittimiç, eme, etmeze, fanti, fileke, giptik, gödelek, hıd, hoç, kıdım, kinifi, kupanca, lame, lofloko, mesmes, moç, ophan, ödek, paya, puka, rampi, rez, șano, siylenbicik, şololu, tıkırcın, tırıngl, tulgara, türşek, yemlekasma, zalaga, zıbbak, zivziv vb.).

Türkiye Türkçesi ağızlarındaki oyun adlarının pek çoğunun Türkçenin ses özelliklerine uymayan kelime ya da kelime grupları oldukları görülmektedir (anergi, badis, cicoz, coli, dallıke, dilġoz, giptik, herlembe, heymafi, holhol, hölüs, kösmali, lame, lapaza, lofloko, mentivar, mumuk, papara, pavle, rlkkım, șarişka, tımırlek, tombili, zıbbak, zıldırzıp vb.). Bununla birlikte, ağızlarda Türkçenin ses özelliklerine uyan oyun adları da bulunmaktadır (analık, ara kesti, atma taş, basmaç, battı balık, çevrim, delikçe, don, eltaşı, evcik, göz yumuk, ikilik, karalama, kayataşı, kolbastı, koşmaca, oyuktaşı, öndört, silgeç, sürütme, taş̧̧akma, üçayak, yumuşacık, yüzlük vb.).

Türkiye Türkçesi ağızlarındaki oyun adları, hem basit (baç, bebek, bır, cicoz, cüz, çır, dız, dim, eme, fileke, güce, hellep, hıd, hoç, hulu, kadal, kellem, kişik, lapaza, mam, nari, patı, tılıs, türşek, zeze, zıkka, zimi vb.) hem türemiş (analık, atmall, batçı, çakmaca, çevrim, delikçe, dolamaç, evcik, göğleme, kalaycı, koşmaca, meşeli, sürütme, süzdürmeç, vızdırak, yeldürme vb.) hem de birleşik kelimeler (aplamsıra, beşaçılan, cancan, corcor, çiftyümbek, eltaşı, eşbulma, hoşbilezik, karsınönü, oyuktaşı, öndört, paşaçömlek, süsensünbül, şırşır, yavrulutavuk $v b$.) şeklinde görülebilmektedir.

Türkiye Türkçesi ağızlarındaki oyun adlarından kelime grubu şeklinde oluşturulanlarda da belirli bir çeşitlilik görülmektedir. Ağızlardaki oyun adlarının sifat tamlaması (altı gol, beş ayak, cincik makarna, çiftyümbek, damaklı met, dokuz kiremit, ġara zelve, hoşbilezik, kırk haydut, kizgın taş, kocaarap, üçayak $v b$.), belirtisiz isim tamlaması (alay turası, avul oyunu, buk kubbezi, çoturum eşeği, göverçin taklasl, hançal barl, kıç dingili, oyuktaşı, pancar havası, Rum kızı, sarhoşbarı,yangınalayı vb.), belirtili isim tamlaması (karsınönü), isim-fiil grubu (ara kesme, aşşuh sekme, baba yıkmaca, çarık kapmaca, çaylak kapışmak, dangılıkırma, deve düzülme, domuzu bataktan çıkarma, eşbulma, göz sahlama, 
katınkırma, kllıç çekme, sekmedikme vb.), sıfat-fiil grubu (beşaçılan, çamur döken, munciğa gömen, topaġaran), unvan grubu (Ali Paşa, Hanım Ayşe, İbrahim Hoca) ya da tekrar grubu(akka dukka, angili bingili, battı battı, bıcı bicl, çatal matal, elik çelik, höl höl, koşum koşum vb.) şeklinde oluşturulduğu görülmektedir. Ayrıca ağızlarda çekimli fiil şeklinde oluşturulan oyun adları da bulunmaktadır (aklın fikrin var mı, ara kesti, darlyand, hamam klzdl, itti bitti, ondi dumana bindi $v b$.).

Ağızlarda varlığını devam ettiren birçok kelime, Türkçe Sözlük’te bulunmamaktadır. Bu çalışmada tespit edilen 821 oyun adından sadece 23 tanesinin Türkçe Sözlük'te bulunması da bu durumun örneklerinden birisidir. Yabancı dillerden alınan veya alınacak kelimeler yerine Türkçenin hayat kaynağı olan ağızlarda yaşayan kelimelerin tercih edilmesi ölçünlü dilimizin yapısal özelliklerini muhafaza etmesinde önemli bir etken olacaktır.

\section{Yararlanılan Tez ve Kitaplar}

Abaz, Ayşe, Çorum-İskilip ve Yöresi A ğızları, Erciyes Üniversitesi Sosyal Bilimler Enstitüsü Yayımlanmamış Yüksek Lisans Tezi, Kayseri, 2004.

Acar, Ergün, Kastamonu Merkez İlçe ve Köyleri Ağzl, Trakya Üniversitesi Sosyal Bilimler Enstitüsü Yayımlanmamış Yüksek Lisans Tezi, Edirne, 2008.

Acer, Fatih, Yerköy ve Yöresi Ağızları, Erciyes Üniversitesi Sosyal Bilimler Enstitüsü Yayımlanmamış Yüksek Lisans Tezi, Kayseri, 2003.

Akar, Ali, Muğla ve Yöresi Ağızları, Türk Dil Kurumu Yayınları, Ankara, 2013.

Akca, Hakan, Ankara İi Ağızları, Türk Kültürünü Araştırma Enstitüsü, Ankara, 2012.

Akyol, Senem, Manisa Merkez Kuzeybatı Köylerinin A ̆gı Özellikleri, Celal Bayar Üniversitesi Sosyal Bilimler Enstitüsü Yayımlanmamış Yüksek Lisans Tezi, Manisa, 2006.

Alkayış, M. Fatih, Adıyaman Ăgzında Atasözleri ve Deyimler, Öncü Basımevi, Ankara, 2012.

Atay, Ayten, Develi ve Yöresi Ăgızları, Erciyes Üniversitesi Sosyal Bilimler Enstitüsü Yayımlanmamış Yüksek Lisans Tezi, Kayseri, 1993.

Atmaca, Emine, Antalya-Korkuteli İlçesi ve Yöresi Ağızları, Türk Dil Kurumu Yayınları, Ankara, 2017. 
Avcı, Şule Aksakal, Yatağan İlçesi Ağızları, Muğla Sitkı Koçman Üniversitesi Sosyal Bilimler Enstitüsü Yayımlanmamış Yüksek Lisans Tezi, Muğla, 2017.

Aydın, Mehmet, Aybastı Ăgzı, Türk Dil Kurumu Yayınları, Ankara, 2002.

Aydoğdu, Özkan, Çankırı İli ve Yöresi Ăgızları, Fırat Üniversitesi Sosyal Bilimler Enstitüsü Yayımlanmamış Doktora Tezi, Elazığ, 2011.

Başer, Elif, Kırıkkale İli Ağızları, Niğde Üniversitesi Sosyal Bilimler Enstitüsü Yayımlanmamış Yüksek Lisans Tezi, Niğde, 2014.

Boz, Erdoğan, Afyonkarahisar Merkez A ğzı, Gazi Kitabevi, Ankara, 2006.

Bozalan, Hale, Bergama Merkez İlçe ve Köylerinde Yaşayan Yörüklerin Ağız Incelemesi, Trakya Üniversitesi Sosyal Bilimler Enstitüsü Yayımlanmamış Yüksek Lisans Tezi, Edirne, 2008.

Bulduk, Türker Barış, Adlyaman İndere (Zey) Köyü Ağzl, Adıyaman Üniversitesi Sosyal Bilimler Enstitüsü Yayımlanmamış Yüksek Lisans Tezi, Adıyaman, 2011.

Bulut, Serdar, Gümüşhane İli ve Yöresi Ağızları Söz Varlı̆̆ı, Gazi Kitabevi, Ankara, 2018.

Buran, Ahmet, Keban, Baskil ve Ağın Yöresi Ağızları, Türk Dil Kurumu Yayınları, Ankara, 1997.

Caferoğlu, Ahmet, Anadolu A ğızlarından Toplamalar, Türk Dil Kurumu Yayınları, Ankara, 1994.

Caferoğlu, Ahmet, Kuzeydoğu İllerimiz Ağızlarından Toplamalar (Ordu, Giresun, Trabzon, Rize ve Yöresi Ağızları), Türk Dil Kurumu Yayınları, Ankara, 1994.

Caferoğlu, Ahmet, Anadolu Illleri Ăğzlarından Derlemeler (Van, Bitlis, Karaköse, Eskişehir, Bolu ve Zonguldak Illleri Ağızları), Türk Dil Kurumu Yayınları, Ankara, 1995.

Caferoğlu, Ahmet, Doğu İllerimiz Ağızlarından Toplamalar (Kars, Erzurum, Çoruh İlbaylıkları Ağızları), Türk Dil Kurumu Yayınları, Ankara, 1995.

Caferoğlu, Ahmet, Güneydoğu İllerimiz Ağızlarından Toplamalar (Malatya, Elazığ, Tunceli, Gaziantep ve Maraş Vilayetleri A Yayınları, Ankara, 1995. 
Caferoğlu, Ahmet, Orta Anadolu Ăğzlarından Derlemeler (Niğde, Kayseri, Kırşshir, Yozgat, Ankara Vilayetleri ile Afşar, Saçıkaralı ve Karakoyunlu Uruklarının Ağızlarl), Türk Dil Kurumu Yayınları, Ankara, 1995.

Çakır, Aylin, İzmir İli Ödemiş-Kiraz-Beydağı İlçesi Ağızları, Ege Üniversitesi Sosyal Bilimler Enstitüsü Yayımlanmamış Doktora Tezi, İzmir, 2018.

Çoban, Esra Kulle, Elmalı ve Yöresi A ğızları, Pamukkale Üniversitesi Sosyal Bilimler Enstitüsü Yayımlanmamış Yüksek Lisans Tezi, Denizli, 2012.

Daban, Engin Burak, Daday İlçesi Ăgzı (Kastamonu İli), Doğu Akdeniz Üniversitesi Sosyal Bilimler Enstitüsü Yayımlanmamış Yüksek Lisans Tezi, Kıbrıs-Gazimağusa, 2015.

Dağcı, Yusuf, Yahyalı (Kayseri) ve Yöresi Ağızlarl, Niğde Üniversitesi Sosyal Bilimler Enstitüsü Yayımlanmamış Yüksek Lisans Tezi, Niğde, 2012.

Demez, Ali, Gölbaşı (Adlyaman) A $\breve{g} z ı$, Erzincan Üniversitesi Sosyal Bilimler Enstitüsü Yayımlanmamış Yüksek Lisans Tezi, Erzincan, 2013.

Demir, İmdat, Sarıgöl ve Yöresi Ağızları, Erciyes Üniversitesi Sosyal Bilimler Enstitüsü Yayımlanmamış Doktora Tezi, Kayseri, 2012.

Demir, Necati, Ordu İli ve Yöresi Ağızları, Türk Dil Kurumu Yayınları, Ankara, 2001.

Demir, Necati, Tokat Illi ve Yöresi Ağızları, Gazi Kitabevi, Ankara, 2006.

Demir, Necati, Trabzon ve Yöresi Ağızları, Gazi Kitabevi, Ankara, 2006.

Demir, Necati \& Şen, Ülker, Sivas İli ve Yöresi Ağızları, Gazi Kitabevi, Ankara, 2006.

Demiray, Erdinç, Kepsut İlçesi ve Yöresi Ăgızları, Niğde Üniversitesi Sosyal Bilimler Enstitüsü Yayımlanmamış Yüksek Lisans Tezi, Niğde, 2003.

Demiray, Gizem, Kırklareli Pınarhisar Merkez İlçesi ve Köyleri Ağız İncelemesi, Trakya Üniversitesi Sosyal Bilimler Enstitüsü Yayımlanmamış Yüksek Lisans Tezi, Edirne, 2008.

Doğan, Muammer, Aksaray ve Yöresi Ağızları, Erciyes Üniversitesi Sosyal Bilimler Enstitüsü Yayımlanmamış Doktora Tezi, Kayseri, 2012.

Elbir, Döne, Ĕgirdir ve Yöresi Ağızları, Süleyman Demirel Üniversitesi Sosyal Bilimler Enstitüsü Yayımlanmamış Yüksek Lisans Tezi, Isparta, 2011. 
Ercilasun, Ahmet Bican, Kars İli Ağızları, Türk Dil Kurumu Yayınları, Ankara, 2002.

Erdem, Mehmet Dursun, \& Bölük, Ramazan, Antalya ve Yöresi Ağızları, Gazi Kitabevi, Ankara, 2012.

Erdem, Mehmet Dursun, \& Kirik, Esra, Kahramanmaraş ve Yöresi Ağızları, Öncü Basımevi, Kahramanmaraş.

Erdoğan, Ferhat, Şuhut ve Yöresi A ̈̆ızları, Afyon Kocatepe Üniversitesi Sosyal Bilimler Enstitüsü Yayımlanmamış Yüksek Lisans Tezi, Afyon, 2007.

Eren, M. Emin, Zonguldak-Bartın-Karabük Illler Ağızları, Türk Dil Kurumu Yayınları, Ankara, 1997.

Erten, Münir, Diyarbakır Ağzı, Türk Dil Kurumu Yayınları, Ankara, 1994.

Gemalmaz, Efrasiyap, Erzurum İli Ağızları, Türk Dil Kurumu Yayınları, Ankara, 1995.

Gökçur, Engin, Van ve Merkez Köyleri Ağızları, Yüzüncü Y1l Üniversitesi Sosyal Bilimler Enstitüsü Yayımlanmamış Yüksek Lisans Tezi, Van, 2006.

Gökçur, Engin, Van Gölü Havzası Ağızları, Fırat Üniversitesi Sosyal Bilimler Enstitüsü Yayımlanmamış Doktora Tezi, Elazı̆g, 2012.

Gönen, Mehmet Emin, Van Gölü Kuzey Havzası Ağızları, Dicle Üniversitesi Sosyal Bilimler Enstitüsü Yayımlanmamış Yüksek Lisans Tezi, Diyarbakır, 2003.

Gül, Rıza, Kilis Merkez ve Köyleri Ağızları, Çukurova Üniversitesi Sosyal Bilimler Enstitüsü Yayımlanmamış Yüksek Lisans Tezi, Adana, 1993.

Gülensoy, Tuncer, Kütahya ve Yöresi Ağızları, Türk Dil Kurumu Yayınları, Ankara, 1998.

Gülensoy, Tuncer \& Buran, Ahmet, Elazı̆̆ Yöresi Ağızlarından Derlemeler, Türk Dil Kurumu Yayınları, Ankara, 1994.

Gülseren, Cemil, Malatya İli Ağızları, Türk Dil Kurumu Yayınları, Ankara, 2000.

Gülsevin, Gürer, Uşak İli Ağızları, Türk Dil Kurumu Yayınları, Ankara, 2002.

Günay, Elif Gözde, Adıyaman-Merkez, Kahta, Gerger, Samsat Yöresi Ağzı, Fırat Üniversitesi Sosyal Bilimler Enstitüsü Yayımlanmamış Yüksek Lisans Tezi, Elazı $\breve{g}, 2008$. 
Günay, Turgut, Rize İli Ağızları, Türk Dil Kurumu Yayınları, Ankara, 2003.

Güneş, İsmail Teoman, Savaştepe Yöresi Yörük Ağızlarının İncelenmesi ve Türkçenin Gelişip Zenginleşmesine Katkıları, Dokuz Eylül Üniversitesi Sosyal Bilimler Enstitüsü Yayımlanmamış Yüksek Lisans Tezi, İzmir, 2009.

Günşen, Ahmet, Kırşehir ve Yöresi Ağızları, Türk Dil Kurumu Yayınları, Ankara, 2000 .

Hünerli, Bülent, Kırklareli Babaeski Merkez İlçesi ve Köyleri Ağız İncelemesi, Trakya Üniversitesi Sosyal Bilimler Enstitüsü Yayımlanmamış Yüksek Lisans Tezi, Edirne, 2006.

İlker, Ayşe, Manisa Ağızları, Türk Dil Kurumu Yayınları, Ankara, 2017.

Kalay, Emin, Edirne İli Ă̆ızları, Türk Dil Kurumu Yayınları, Ankara, 1998.

Kaymaz, Muhammet, Sivrice Yöresi Ağızlarl, Firat Üniversitesi Sosyal Bilimler Enstitüsü Yayımlanmamış Yüksek Lisans Tezi, Elazığ, 1996.

Kılıçer, İsmail, Yozgat ve Yöresi Ağızları, Yüzüncü Yıl Üniversitesi Sosyal Bilimler Enstitüsü Yayımlanmamış Yüksek Lisans Tezi, Van, 1998.

Koca, Sinan, Görele ve Yöresi Ağızları, Giresun Üniversitesi Sosyal Bilimler Enstitüsü Yayımlanmamış Yüksek Lisans Tezi, Giresun, 2015.

Koraş, Hikmet, Karaman ve Yöresi Ağızları, Erciyes Üniversitesi Sosyal Bilimler Enstitüsü Yayımlanmamış Yüksek Lisans Tezi, Kayseri, 1992.

Korkmaz, Zeynep, Bartın ve Yöresi Ağızları, Türk Dil Kurumu Yayınları, Ankara, 1994.

Korkmaz, Zeynep, Güney-Batı Anadolu Ağızları, Türk Dil Kurumu Yayınları, Ankara, 1994.

Korkmazyiğit, Ahmet, Çayıralan ve Yöresi Ăgızları, Erciyes Üniversitesi Sosyal Bilimler Enstitüsü Yayımlanmamış Yüksek Lisans Tezi, Kayseri, 2010.

Kök, Abdullah, Oğuzeli ve Yöresi Ağızları, Van Yüzüncü Yıl Üniversitesi Sosyal Bilimler Enstitüsü Yayımlanmamış Yüksek Lisans Tezi, Van, 1995.

Mutlu, Hüseyin Kahraman, Balıkesir İli Ağızlarl, Gazi Üniversitesi Sosyal Bilimler Enstitüsü Yayımlanmamış Doktora Tezi, Ankara, 2008.

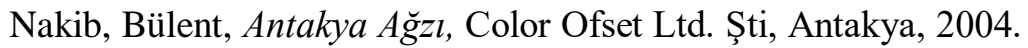


Nas, Gönül Erdem, Anamur ve Yöresi Ağızları, Erciyes Üniversitesi Sosyal Bilimler Enstitüsü Yayımlanmamış Doktora Tezi, Kayseri, 2014.

Olcay, Selahattin, Doğu Trakya Yerli Ăgzı, Türk Dil Kurumu Yayınları, Ankara, 1995.

Olcay, Selahattin, Ercilasun, Ahmet Bican, \& Aslan, E., Arpaçay Köylerinden Derlemeler, Türk Dil Kurumu Yayınları, Ankara, 1998.

Öçalan, Muharrem, Sakarya İli Ağızları, Erciyes Üniversitesi Sosyal Bilimler Enstitüsü Yayımlanmamış Doktora Tezi, Kayseri, 2004.

Özçelik, Saadettin, Urfa Merkez Ağzı, Türk Dil Kurumu Yayınları, Ankara, 1997.

Özçelik, Saadettin \& Boz, Erdoğan, Siverek Merkez Ağzl, Gazi Kitabevi, Ankara, 2009.

Özden, Muharrem, Bilecik İli Ă̆gz İncelemesi, Trakya Üniversitesi Sosyal Bilimler Enstitüsü Yayımlanmamış Doktora Tezi, Edirne, 2009.

Özkaya, Hakkı, Kırklareli İli Ă̆ızları Söz Varlı̆̆ı, Trakya Üniversitesi Sosyal Bilimler Enstitüsü Yayımlanmamış Yüksek Lisans Tezi, Edirne, 2013.

Öztürk, Jale, Hatay A ̆gzl, Karahan Kitabevi, Adana, 2009.

Polat, Fadime, Şavşat ve Yöresi Ağızları, Erciyes Üniversitesi Sosyal Bilimler Enstitüsü Yayımlanmamış Yüksek Lisans Tezi, Kayseri, 2000.

Sağır, Mukim, Erzincan ve Yöresi Ağızları, Türk Dil Kurumu Yayınları, Ankara, 1995.

Sert, Göksel, Eskişehir İli Yörük Ağızları, Osmangazi Üniversitesi Sosyal Bilimler Enstitüsü Yayımlanmamış Yüksek Lisans Tezi, Eskişehir, 2015.

Sinan, Ahmet Turan, Akçadă̆, Doğanşehir ve Darende Ăgızlarl, Fırat Üniversitesi Sosyal Bilimler Enstitüsü Yayımlanmamış Yüksek Lisans Tezi, Elazı $\breve{g}, 1992$.

Taş, Pınar, Şarkışla ve Yöresi Ağızları, Erciyes Üniversitesi Sosyal Bilimler Enstitüsü Yayımlanmamış Yüksek Lisans Tezi, Kayseri, 2006.

Tayşi, Mustafa, Tavşanlı ve Yöresi Ağız İncelemesi, Dumlupınar Üniversitesi Sosyal Bilimler Enstitüsü Yayımlanmamış Yüksek Lisans Tezi, Kütahya, 2007.

Tekin, Feridun, Kaman ve Yöresi Ağızları, Erciyes Üniversitesi Sosyal Bilimler Enstitüsü Yayımlanmamış Yüksek Lisans Tezi, Kayseri, 1994. 
Telli, Burak \& Bulduk, Türker Barış, Adlyaman İli ve Yöresi Ağızları Söz Varlığı. Gazi Kitabevi, Ankara, 2018.

Tosun, İbrahim, Çemişgezek, Pertek ve Hozat Yöresi Ağızları, Fırat Üniversitesi Sosyal Bilimler Enstitüsü Yayımlanmamış Yüksek Lisans Tezi, Elazığ, 1996.

Tosun, İlker, Tekirda $\breve{g}$ Merkez İlçe ve Köyleri Ağızları, Trakya Üniversitesi Sosyal Bilimler Enstitüsü Yayımlanmamış Yüksek Lisans Tezi, Edirne, 2003.

Uysal, İdris Nebi, Karaman İli Ağızları ve Anadolu Ağızları Arasındaki Yeri, Pamukkale Üniversitesi Sosyal Bilimler Enstitüsü Yayımlanmamış Doktora Tezi, Denizli, 2009.

Ünal, Ergül, Reşadiye ve Yöresi Ağızları, Gaziantep Üniversitesi Sosyal Bilimler Enstitüsü Yayımlanmamış Yüksek Lisans Tezi, Gaziantep, 2010.

Ünlü, Eren, Gümüşhane Illi Şiran ve Köse Illçeleri Ağızları, Adıyaman Üniversitesi Sosyal Bilimler Enstitüsü Yayımlanmamış Yüksek Lisans Tezi, Adiyaman, 2015.

Yapıcı, Ali İhsan, Aydın ve Yöresi Ăğzları, Muğla Sttkı Koçman Üniversitesi Sosyal Bilimler Enstitüsü Yayımlanmamış Doktora Tezi, Muğla, 2013.

Yavuz, Serdar, Adıyaman İli ve Yöresi Ağızları, Turkish Studies Yayınları, Ankara, 2013.

Yaylağan, Nilay, Isparta'nın Eğirdir, Senirkent ve Atabey İlçelerinin Ăgız Özelliklerinin Tespiti ve Türkçe Eğitimi Bakımından Önemi, Dokuz Eylül Üniversitesi Sosyal Bilimler Enstitüsü Yayımlanmamış Yüksek Lisans Tezi, İzmir, 2010.

Yeşilkaya, Mehmet, Adlyaman-Gerger Ăgzz, Van Yüzüncü Yıl Üniversitesi Sosyal Bilimler Enstitüsü Yayımlanmamış Yüksek Lisans Tezi, Van, 2007.

Yıldırım, Kübra Dilaver, Bergama Yöresi Tahtacı ve Çepni Ağızları, Trakya Üniversitesi Sosyal Bilimler Enstitüsü Yayımlanmamış Yüksek Lisans Tezi, Edirne, 2013.

Yıldırım, Ünal, Ayrancı (Karaman) Yöresi Ăgızları, Fırat Üniversitesi Sosyal Bilimler Enstitüsü Yayımlanmamış Yüksek Lisans Tezi, Elazı̆̆, 2007.

\section{Kisaltmalar}

AA: Ankara İli Ağızları 
AAT: Anadolu Ağızlarından Toplamalar

AİAD: Anadolu İlleri Ağızlarından Derlemeler

AİYA: Adıyaman İli ve Yöresi Ağızları Söz Varlığı

AMA: Afyonkarahisar Merkez Ağzı

AŞA: Afyon Şuhut ve Yöresi Ağızları

BA: Bilecik İli Ağız İncelemesi

BİA: Balıkesir İli Ağızları

BRA: Eski Türkçe Cümle Yapılarının Modern Türkçenin Ağızlarında Kullanımı: Bursa-Boğazköy Ö.

BSA: Balıkesir Savaştepe Ağzı

ÇA: Çankırı İli ve Yöresi Ağızları

DS: Derleme Sözlüğü

EİA: Edirne İli Ağızları

EYA: Eskişehir İli Yörük Ağızları

EYAD: Elazı̆̆ Yöresi Ağızlarından Derlemeler

GA: Gümüşhane İli ve Yöresi Ağızları Söz Varlığı

GGA: Giresun Görele ve Yöresi Ağızları

GİAT: Güneydoğu İllerimiz Ağızlarından Toplamalar

GŞKA: Gümüşhane Şiran ve Köse İlçeleri Ağzı

HAA: Hatay Arsuz Ağzı

IEA: Isparta Eğirdir A ğZ1

KA: Karaman Ağz1

KAKD: Kars Arpaçay Köylerinden Derlemeler

KDA: Kastamonu Daday Ağz1 
KİA: Kars İli Ağızları

KİAT: Kuzeydoğu İllerimiz Ağızlarından Toplamalar

KRA: Kırklareli İli Ağızları Söz Varlığı

KSA: Kastamonu Merkez İlçe ve Köyleri Ağzı

KYA: Kırşehir ve Yöresi Ağızları

MA: Manisa Ağızları

MAA: Manisa Alaşehir Ağzı

MİA: Malatya İli Ağızları

MSA: Manisa Sarıöl ve Yöresi Ağızları

MYA: Muğla ve Yöresi Ağıları

OAA: Ordu Aybastı Ağzı

OAAD: Orta Anadolu Ağızlarından Derlemeler

OTA: Osmaniye Tatar Ağzı

RİA: Rize İli Ağızları

SIYA: Sivas İli ve Yöresi Ağızları

sz.: Sözlük

TiYA: Tokat İli ve Yöresi Ağızları

TYA: Trabzon ve Yöresi Ağızları

TYAD: Tunceli Yöresi Ağızlarından Derlemeler

UİA: Uşak İli Ağızları

UMA: Urfa Merkez Ağzı

USA: Urfa Siverek Merkez Ağz1

vb.: Ve benzeri

VHA: Van Gölü Havzası Ağızları 


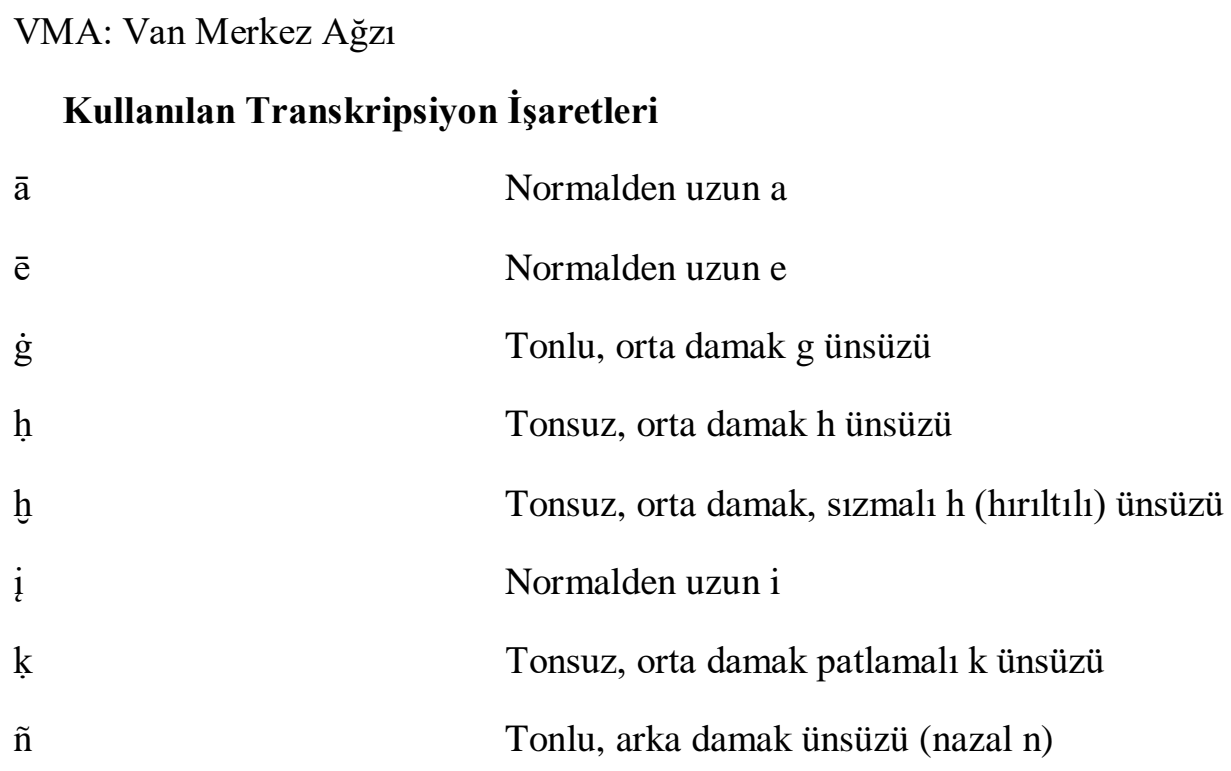

KAYNAKÇA

And, Metin (2003), Oyun ve Bügü, Yapı Kredi Yayınları, İstanbul.

Atalay, Besim (2018), Divanü Lugat-it Türk (Dizin), Türk Dil Kurumu Yayınları, Ankara.

Bali, Aslı (2017),"Halk Oyunları Üzerine Bilimsel Bir Araştırma: Mersin İli Silifke İlçesi Örneği", Karadeniz Dergisi, S. 33, s. 78-91.

Başal, Handan Asude (2007),"Geçmiş Yıllarda Türkiye'de Çocuklar Tarafindan Oynanan Çocuk Oyunları", Uludağ Üniversitesi Eğitim Fakültesi Dergisi, S. 20, s. 243-266.

Dilçin, Cem (1983), Yeni Tarama Sözlüğ̈̈, Türk Dil Kurumu Yayınları, Ankara.

Doğan, D. Mehmet (2001),Büyük Türkçe Sözlük, Vadi Yayınları, Ankara.

Ekmekçioğlu İsmail, Bekar Cüneyt, Kaplan Metin (2001), Türk Halk Oyunları, Esin Yayınevi, İstanbul.

Telli, Burak (2019). "Hatay Ağzından Derleme Sözlüğü'ne Katkılar", Tarih Okulu Dergisi, XXXVIII, ss. 664-693.

Türk Dil Kurumu (1998), Türkçe Sözlük, 9. Bask1, Türk Dil Kurumu Yayınları, Ankara. 
Türk Dil Kurumu (2009), Derleme Sözlüğ̈̈̈,3. Bask1, Türk Dil Kurumu Yayınları, Ankara.

Onur, Bekir (1992), Oyuncaklı Dünya, V Yayınları, Ankara. 